\title{
An Armour from a finery?- - a late medieval couter from Ogrodzieniec Castle in the Kraków-Częstochowa Jura
}

\author{
Ewelina Imiołczyk ${ }^{1} \cdot$ Grzegorz Żabiński $^{2}$ (1) - Tomasz Goryczka ${ }^{3} \cdot \mathrm{Krzysztof} \mathrm{Aniołek}^{3} \cdot$ Agnieszka Balińska $^{4} \cdot$ \\ Ewelina Miśta-Jakubowska ${ }^{5}$
}

Received: 1 July 2019 / Accepted: 14 November 2019 / Published online: 31 January 2020

(C) The Author(s) 2020

\begin{abstract}
The paper deals with a couter of a late fourteenth to early fifteenth century date which was found in Ogrodzieniec Castle, Zawiercie District, Poland (now in the collection of the Upper Silesian Museum in Bytom, MG 7755). The find survived in a vestigial condition, but it was still possible to propose some typological analogies to it. Metallographic examinations demonstrated that the artefact had been manufactured from almost carbon-free iron with a high content of phosphorus. An analysis of slag inclusions in the find suggests that the couter may have been made from refined blast furnace iron. It may thus be an early example of the application of indirect process iron in the manufacture of plate armour.
\end{abstract}

Keywords Fourteenth-fifteenth century · Late Middle Ages · Ogrodzieniec Castle · Poland · Plate Armour · Couter . Archaeometallurgy $\cdot$ Archaeometry $\cdot$ Multivariate statistics $\cdot$ Slag inclusion analysis $\cdot$ Iron smelting process identification $\cdot$ Blast furnace $\cdot$ Indirect smelting process $\cdot$ History of metallurgy

\section{Context of discovery}

The couter in question was discovered in the ruins of Ogrodzieniec Castle, Zawiercie District in the KrakówCzestochowa Jura, Poland. The castle is located on a hill at the height of $504 \mathrm{~m}$ asl in the village of Podzamcze, c. $1.5 \mathrm{~km}$ to the east of Ogrodzieniec (Map 1). The origin of the premise may be dated to the early thirteenth century, and a Gothic castle was built there probably in the 1360s during the reign of King Kazimierz the Great. In the fifteenth century, the castle was redeveloped, and new masonry buildings were constructed, including a three-storey dwelling tower and a wing

Grzegorz Żabiński

g.zabinski@gmail.com

Ewelina Imiołczyk

e.gabala@muzeum.bytom.pl

Tomasz Goryczka

tomasz.goryczka@us.edu.pl

Krzysztof Aniołek

krzysztof.aniolek@us.edu.pl

Agnieszka Balińska

a.balinska@ajd.czest.pl with a bastion. In the years 1532-1547, the premise underwent a thorough rebuilding by Seweryn Boner. Most of the original castle was pulled down, and a Renaissance-style residence was constructed in its place (on the castle itself see, e.g., Lachowska 2015; Antoniewicz 1993; Gruszecki 1977).

In 1964, archaeological excavations were launched at the castle by the Archaeology Department of the Upper Silesian Museum in Bytom under the supervision of J. Szydłowski. A trench was laid out in the courtyard along the N-S axis next to the castle's main gate. The couter was recorded at the depth of $0.3-0.5 \mathrm{~m}$ in Layer 4. This layer was composed of black humid soil with organic remains such as pieces of timber, dung, and

Ewelina Miśta-Jakubowska

Ewelina.Mista@ncbj.gov.pl

1 Upper Silesian Museum in Bytom, Silesian University, Katowice, Poland

2 Institute of History, Jan Długosz University in Częstochowa, Al. Armii Krajowej 36a, 42-200 Częstochowa, Poland

3 Institute of Materials Science, Silesian University, Katowice, Poland

4 Faculty of Mathematics and Natural Science, Jan Długosz University in Częstochowa, Częstochowa, Poland

5 National Centre for Nuclear Research, Świerk, Otwock, Poland 


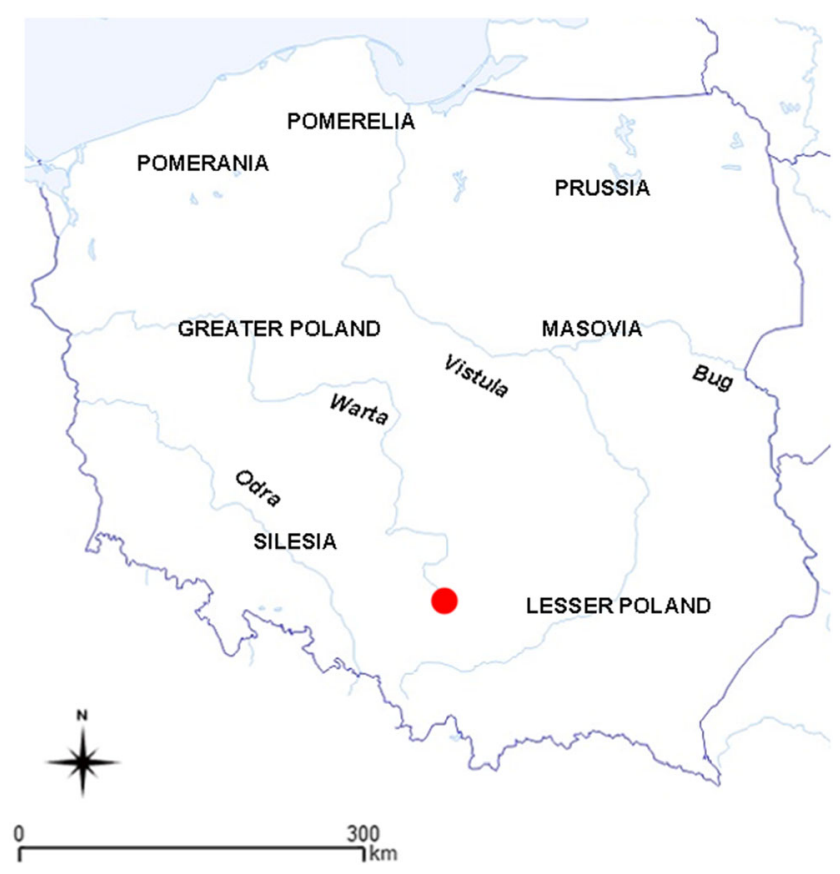

Map 1 Ogrodzieniec Castle - site location. G. Żabiński

animal bones, as well as numerous artefacts, including brick fragments, glazed and unglazed pottery shards, and two nails. Below Layer 4, there was undisturbed subsoil. Layer 4 was believed to be related to the earliest period of use of the castle, and the pottery shards were tentatively dated to the fourteenth or early fifteenth century (Szydłowski 1964; Dziennik badań w Ogrodzieńcu 1964). On the other hand, a closer inspection of pottery finds suggests that their chronology may be shifted even to the second half of the fifteenth or the early sixteenth century. Thus, the layer in question may have originated in the period of the castle's rebuilding in 1532-1547.

\section{Description and chronology}

The couter has survived in a vestigial form. It is bowl-shaped and conical, with a feebly pronounced central rib. Its height is $9.6 \mathrm{~cm}$ and its width is $8.8 \mathrm{~cm}$. The thickness of the metal sheet is $1.33-1.62 \mathrm{~mm}$ near the edges and $0.81 \mathrm{~mm}$ near the rib. Near one of the artefact's edges, there is a globular empty rivet head, and c. $4.5 \mathrm{~cm}$ from it there is a small opening (2.93-3.20 $\mathrm{mm}$ in diameter), which may be a remain of another rivet. The total number of these rivets is difficult to determine, as the edges of the couter are very strongly damaged and they survived in their original shape in one place only. The rivets may have fastened leather straps or may have fulfilled an ornamental role only (Fig. 1a-c). It is difficult to say whether the couter from Ogrodzieniec was provided with side wings or ailettes (Fig. 1d), but such a possibility cannot be excluded. The couter was perhaps part of an entire arm defence, which also encompassed a pauldron (spaulder), a vambrace, a rerebrace and a gauntlet (see, e.g., Szymczak 2016: p. 118).

In view of the absence of reliable stratigraphical dating of the artefact, its chronology must be proposed solely on the basis of morphological criteria. The presence of the edge and the shape of the couter would suggest a period between the early fourteenth century and about 1430. Due to the fragmentary state of preservation of the find, it is difficult to unambiguously classify it using the typology proposed by Goll. On the basis of the present shape of the couter, it could be classified as Type I, i.e., couters which protected the elbow only. However, bearing in mind the presence of rivets, it could also be Type II, that is, couters which protected the internal side of the elbow, too (Goll 2014: p. 43).

For the same reason, it is not easy to propose convincing analogies. Archaeological finds of counters from the presentday territory of Poland are sparse. A reasonable analogy can be offered by a couter from a motte-type stronghold in Siedlątków, Poddębice District, Central Poland. Its shape is globular-conical with a semicircular wing, and the chronology of the entire armour is c. 1360/1370-1380 (Szymczak 2016: p. 120; Nowakowski 2006: pp. 140, 380, P1. 138; Nowakowski 1990: pp. 67, 78, 80-81, Pl. XX; Nadolski 1969: pp. 10-12, Fig. 3, 16, Pl. III). Three Gothic couters are known from a knightly residence in Spytkowice, Wadowice District, Lesser Poland, and their chronology is about 1470-1500 (Klimek and Strzyż 2011: pp. 217, Fig. 2, 5-6, 218; Nowakowski 2006: pp. 144, 388-389, Pls. 146147; Glinianowicz 2005: pp. 145-146, Pl. 3, 147-148; Nowakowski 2003: pp. 95-96, Fig. 20c; Nadolski and Wawrzonowska 1982: pp. 23-24, Figs. 29-34). However, their shape is very different from that from Ogrodzieniec these are elongated, sharp-pointed, and ornamented with grooves.

It is believed that the earliest ferrous metal couters came into existence in the early fourteenth century (see recently Dowen 2017: pp. 22-23, Fig. 6; Goll 2014: p. 54; see also Grabarczyk 1992: p. 78; Oakeshott 1999, 284). One of the earliest examples of plate arm defences with couters is those belonging to Charles IV Dauphin of France, dated to the second half of the fourteenth century (Żygulski 1975: p. 105). A good example of a couter with a horizontal rib can be seen in a depiction from a letter of Christine de Pisan from the early fifteenth century (Fig. 1e). Numerous instances of plate couters which are somewhat similar to the find from Ogrodzieniec are known from medieval iconography in what is now Poland. One of the first examples of primitive couters can be seen on the tombstone of Pakosław Lis of Mstyczów in the Cistercian monastery in Jędrzejów, Jędrzejów District in Lesser Poland (c. 1325) (Nowakowski 2003, p. 93). Furthermore, semi-globular couters with short wings are depicted on the tombstone of Duke Bolko I and Duke Bolko 
II of Opole (Oppeln) in the Franciscan church in Opole (Oppeln), Silesia (c. 1370-1380) (Kajzer 1976: p. 149, Fig. 37a-b; Wawrzonowska 1976: pp. 113-114, cat. Nos. 20-21, Pl. XV). Similar couters can also be seen on the tombstone of Duke Bolko II of Świdnica (Schweidnitz) (died 1368) in the Cistercian church in Krzeszów (Grüssau), Kamienna Góra District, Silesia (after 1375). These couters are provided with rivets near the edge (Nowakowski 1990: p. 521, Fig. 83; Kajzer 1976: p. 149, Fig. 37c). Yet another early example is a c 1390 fresco in Lochstedt Castle, now Pavlovo, part of Baltiysk (Pilau), Kaliningrad Region, Russia. The Teutonic
Wardrobe Master wears a couter with a well-pronounced ridge (Nowakowski 1994: p. 149, Fig. 48). Conical couters can also be found in iconographic sources from late medieval Bohemia (Nowakowski 1990: p. 80).

Kajzer says that couters with wings appear in the second half of the fourteenth century (Kajzer 1976: p. 110). In the opinion of Nowakowski, wings on couters were popular in the first half of the fifteenth century, and then they were replaced with round shields attached to vambraces or rerebraces (Nowakowski 2003: p. 96; see also Kajzer 1976: p. 126).
Fig. 1 Couter from Ogrodzieniec, Zawiercie District, Upper Silesian Museum in Bytom, MG 7755. a, view from above, photo $\mathrm{W}$. Szołtys; $\mathbf{b}$, view from above and from the side, drawing $\mathrm{E}$. Imiołczyk; $\mathbf{c}$, opening near the edge (marked with an arrow), photo W. Szołtys; d, putative reconstruction, background photo after Goll 2014, ref. arm 362,006, by E. Imiołczyk; $\mathbf{e}$ - couter with a horizontal rib, letter of Christine de Pisan, early fifteenth century, http://gallica.bnf.fr/ark:/12148/ btv1b8448967x/f27.image, accessed on 10 February 2018; F - couter with a vertical rib, Rafał of Gołuchów on the painting of Madonna $a b$ Igne in Kalisz, Greater Poland (c. 1425-1450), after Nowakowski 2006: p. 321, Pl. 79
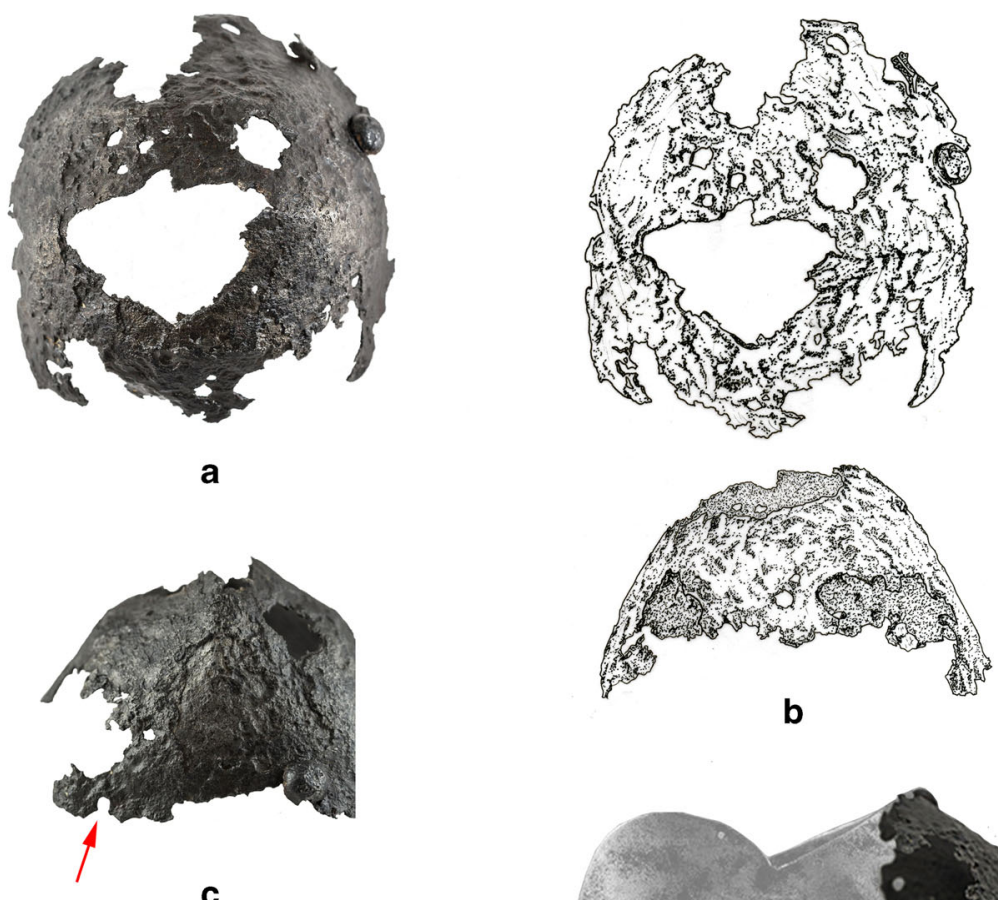

$10 \mathrm{~cm}$
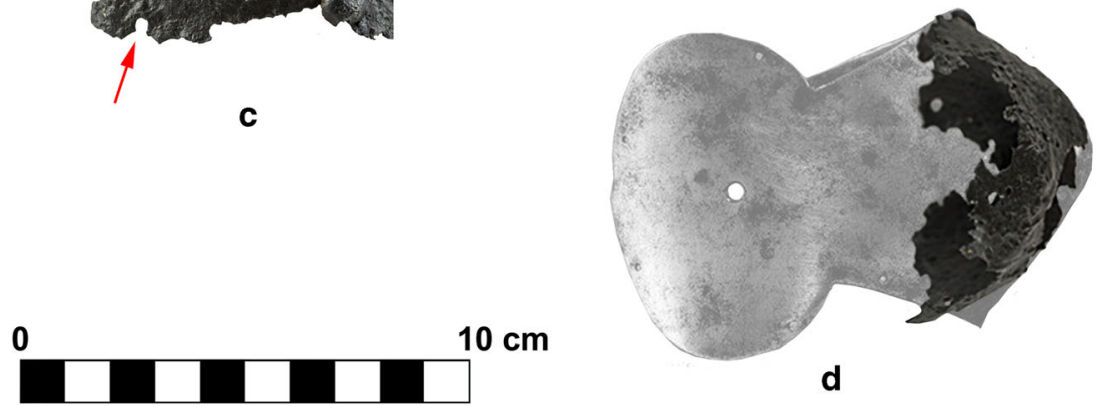

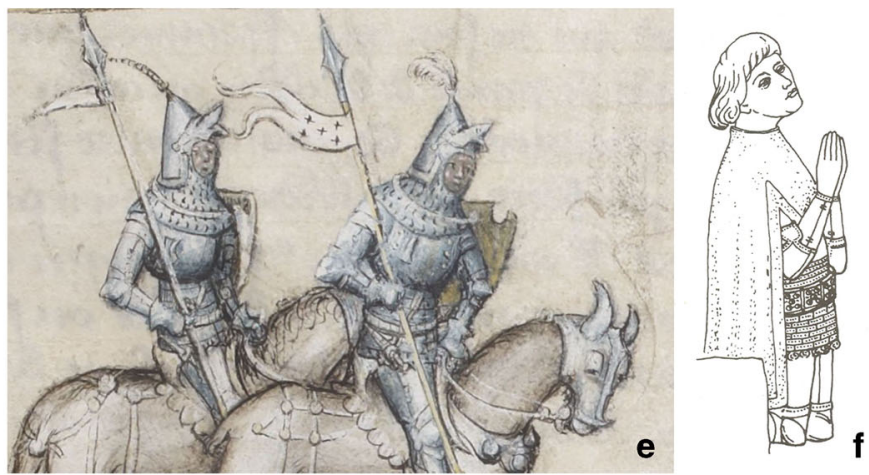


Regarding depictions of conical couters with short wings which are dated to the first half of the fifteenth century, such artefacts can be seen on the epitaph of Wierzbietta of Branice (c. 1425) in the National Museum in Kraków (Nowakowski 2006: pp. 133, 249, Pl. 7; Nowakowski 1990: pp. 81, 515, Fig. 70; 249; Kajzer 1976: pp. 63, Fig. 12, 71, cat. No. 5). Similar couters were depicted on the tombstone of Wierzbięta in the church in Ruszcza (now part of Kraków-Nowa Huta), also dated to c. 1425 (Nowakowski 2006: pp. 133, 251, Pl. 9; Nowakowski 1990: p. 511, Fig. 56; Kajzer 1976: pp. 63, Fig. 12, 71, cat. No. 6). Conical couters with lily-shaped side wings can be seen on the foundation plate of Dobiesław of Oleśnica, Sienno, Lipsko District in Lesser Poland (c. 1432) (Nowakowski 2006: pp. 133, 254, Fig. 12; Nowakowski 1990: pp. 81, 493, Pl. XI; Kajzer 1976: pp. 72-73, cat. No. 8, Fig. 14). Another example is the tombstone of Jan of Sprowa in the Cistercian abbey in Mogiła, Kraków (1440s) (Nowakowski 2006: p. 256, Fig. 14; Nowakowski 1990: p. 511, Fig. 57; Kajzer 1976: pp. 72, cat. No. 9, 74, Fig. 15). Conical couters with vertical ribs are worn by Rafał of Gołuchów on the painting of Madonna ab Igne in Kalisz, Greater Poland (c. 1425-1450) (Fig. 1f) (Nowakowski 2006: p. 321, Pl. 79; Nowakowski 1990: pp. 81, 514, Fig. 71; Kajzer 1976: p. 157, Fig. 45b). Round shields on or as couters can also be seen on the depiction of Jakub Rożen on the Jurków Triptych, now in Czchów, Brzesko District, Lesser Poland (c. 1440-1446) (Nowakowski 2006: p. 269, Pl. 27; Nowakowski 2003: Fig. 49; Nowakowski 1990, pp. 515, Fig. 74a; Kajzer 1976, pp. 72-73, cat. No. 11, Fig. 17).

Similar shapes are also the case on later depictions from the second half of the fifteenth century, for instance, on the tombstone of Jan Kobyleński in the Dominican church in Kraków (c. 1471) (Nowakowski 2006: p. 274, Pl. 32; Nowakowski 2003: p. 96, Fig. 48; Kajzer 1976: pp. 74, cat. No. 15, 82, Fig. 21). Conical couters with ribs can also be seen on the epitaph of Rafał Tarnowski in the church in Przeworsk, Przeworsk District, Lesser Poland (c. 1490) (Nowakowski 2003: Fig. 46; Kajzer 1976: pp. 75, cat. No. 17, 83, Fig. 23). In general terms, among various armour styles, the Ogrodzieniec couter seems to best match the German "alwite" style from the first half of the fifteenth century (Oakeshott 2000: pp. 82-84, Fig. 24). This is not surprising, as German influences were quite strong with regard to arms and armour in this part of Europe.

\section{Metallurgy of European armour}

There has been a lot of research on the metallurgy of European armour since Antiquity to the Modern Period. Therefore, some main trends are generally well-known. Regarding Roman plate armour, both iron and steel (from pure iron to high-carbon pearlitic steel) were in use, but it seems that ferritic metal was preferred. Carburising was sometimes applied, but no quenching was used, and the hardness was generally below $300 \mathrm{HV}$ (in most cases between 203 and $263 \mathrm{HV}$ ). It was assumed that hardness had not been the most important priority for Roman armourers, and the most armours had been perhaps not hardened intentionally. On the other hand, cold hardening by hammering may sometimes be supposed. As implied by examples of Roman armour from Northern Britain, the metal was generally quite clean concerning its slag content. In more than $2 / 3$ of the examined samples, the content of slag was less than $4 \%$, as measured by its share in the surface of the sample. Interestingly, in most cases, the armour was made from more than one piece of metal and iron and steel were sometimes used together (Fulford et al. 2005: pp. 243-245, Table 1, 246-248, Figs. 3-4; Fulford et al. 2004: pp. 200-205, Table 1, 206-208, Fig. 8, 211-212, 216-217, Figs. 13-14, 220). Regarding examined examples of Merovingian Period lamellar armour from Germany, low-carbon steel was used which excluded any heat-treatment (Becker and Riesch 2002: 600-602, Figs. 3-6).

With regard to medieval plate armour, what is known of its metallurgy is chiefly due to authoritative studies by Williams. As it is known, in late medieval Europe, there were two most renown armour-making regions, that is, North Italy and South Germany. Regarding Italian armour, in the fifteenth century it was almost always made of steel (low- or medium-carbon), while iron was in use sporadically. More than a half of examined artefacts which were provided with manufacturer's marks were hardened by heat treatment, while those without marks were hardened in more than $25 \%$ cases only (Williams 2003: pp. 62-67, Tables. 1-2; for individual examples, see ibid.: pp. 74-201; for newer examinations see, e.g., Williams and Edge 2004: pp. 124-126, 130-132, Figs. 7-13; Williams 2011: pp. 165-166, Fig. 68a, 167-168, Fig. 69-71, 169-172, Figs. 7274; Williams and Edge 2013: pp. 197-198, 200, 202-203, Figs. 1, 204, Figs. 2, 206, Fig. 6). After c. 1510, Italian armour was almost never manufactured from hardened steel. This may have been a result of the application of fire-gilding or may have been caused by war-related economic difficulties in Italy (Williams 2003: pp. 203-205).

As far as German plate armour is concerned, it must first of all be said that before the late fifteenth century, it was not provided with marks of manufacturers or towns, which is why it is difficult to identify its origin. In most cases, such armours were made from iron or low-carbon steel, while medium-carbon steel was rarely used. In this period, German armours were almost never hardened, which is why Italian armours were considered far superior. On the other hand, in the last quarter of the fifteenth century, steel became more popular and full quenching and tempering went into use on a regular basis. Marks became widespread, which seems to imply that German armours were exported and as such had to 
be identifiable (Williams 2003: pp. 331-333; for individual examples, see ibid.: pp. 334-360; for more recent examinations, see, e.g., Williams and Edge 2013: pp. 197-198, 201, 203, Fig. 1, 204, Fig. 3). With regard to individual South German centres, most armours made in Augsburg between c. 1470 and c. 1500 were made from medium-carbon steel and were hardened by heat treatment. In the later period (until c. 1630), this tendency continued, albeit the share of hardened armours was somewhat lower (Williams 2003: pp. 361-368; for individual examples, see ibid.: pp. 373-398). More or less the same can be said concerning Innsbruck armour in the period between c. 1450 and c. 1520 , with a remark that the process of hardening by heat treatment was introduced there $\mathrm{c}$. 1485 and a preponderance of low- and medium-carbon steel over iron (only one case) was even more pronounced (Williams 2003: pp. 451-458; for individual examples, see ibid.: pp. 463-507; see also id. 2012: pp. 207-208). The case of Landshut armour is pretty similar. It is of interest that legal regulations of that town from 1479 stated that armour had to be all-steel, and it seems that this principle was in fact obeyed (Williams 2003: pp. 551-554, for individual examples, see ibid.: pp. 558-567). A similar rule was introduced in 1478 in Nürnberg. On the other hand, in the late fifteenth to sixteenth century, this city became a centre of manufacture of mass-made munition armours, which were manufactured either from iron or low-carbon steel (Williams 2003: pp. 589597). Regarding late medieval and early modern armour from other regions of Europe, it seems that low- or medium-carbon steel generally prevailed over iron, but hardening by heat treatment was not that common (Williams 2003: pp. 684713, 731, 740-746, 816, 832; see also, e.g., Marek 2008; Williams 2009: pp. 213-215, Figs. 1-6, 216-218, Figs. 718, 219; Marek 2014: pp. 132, 139-140, Fig. 8.3-6).

Williams also paid attention to the issue of use of blast furnace metal. He supposed that refined blast furnace iron had in all probability been used in the manufacture of cheap lower quality armour in the sixteenth century. This assumption was generally based on its very low cost, which may imply mass supply of cheap iron (Williams 2003: pp. 886-889, 891; see also id. 2012: pp. 201, 212-213; on low-quality modern period field armour, see also Vella et al. 2004: pp. 217-231).

Regarding more specific examples of plate armour made from iron or very low-carbon steel (c. $0.1 \mathrm{C} \%$ ), attention is drawn to the bascinet visor from the North Italian armour Churburg 13 (c. 1360-1370). Its metal was composed of ferrite with a small amount of carbides and its hardness varied from 110 to $236 \mathrm{VPH}$ (Williams 2003: pp. 69-70). Other examples are c. 1450-1470 barbutas from the Royal Armoury in Turin (inv. Nos. E7 and E9), which were made from ferritic metal with slag inclusions (Williams 2003: pp. 109, 113). The same was the case with the right vambrace of the armour Churburg 47 (c. 1360-138) (Williams 2003: pp. 157) and a c. 1450 helmet from the Metropolitan Museum of
Art in New York (inv. No. 49.120.8) (Williams 2003: p. 178). The same museum holds a sallet of possibly German provenance (inv. No. 29.150.12) which was made from low-carbon steel with less than $0.1 \%$ C. The artefact is dated to c. 1450 1460 (Williams 2003: p. 686). An interesting example is posed by the armour Churburg 18 (c. 1370-1410), whose individual parts were made either from ferritic metal or from very low-carbon steel (Williams 2011: pp. 164-166, Figs. 6667). Low-carbon steel with c. $0.1 \% \mathrm{C}$ was used for the manufacture of mid-fourteenth-century gauntlets of perhaps English provenance from the Royal Armouries in Leeds (inv. No. III.773) (Williams 2003: p. 356). Almost carbonfree metal was the case in a plate above the couter from the left elbow defence kept in the Royal Armoury in Turin, dated to c. 1490 (inv. No. C.2) (Williams 2003: p. 136). With regard to the strong presence of phosphorus in the discussed couter from Ogrodzieniec, a high content of $\mathrm{P}$ was also identified in the right pauldron of a North Italian amour (c. 1600-1650) from the Armoury of the Grand Masters of the Order of St John's Palace in Valletta, Malta (inv. No. PA RC 165). The metal was ferrite with numerous slag inclusions (Vella et al. 2004: pp. 221, Table 1, 229, Fig. 8a-b, 230, Table 2).

Furthermore, among the examined examples of plate armours there were also couters and their technology varies considerably. The right couter of an Italian armour from Rhodes (c. 1495), now in the Royal Armouries in Leeds (III.1115), was made from ferritic-pearlitic metal with c. $0.2 \% \mathrm{C}$. The artefact was air-cooled after forging (Williams 2003: p. 141). On the other hand, other examples were made with the use of more complex technologies. A c. 1490 couter, perhaps manufactured by Lorenz Helmschmied (private collection of J. Mann), displayed microstructures with tempered martensite, some ferrite, and very few slag inclusions (Williams 2003: p. 384). Heat treatment was also the case in the Churburg 71 couter (c. 1505-1510) made by Hans Seusenhofer from Innsbruck. In its microstructures, there were ferrite, pearlite, and martensite, and hardness values varied between 251 and 483 VPH (Williams 2003: pp. 493-494). An interesting example is also posed by two early modern period couters from the Fitzwilliam Museum in Cambridge (inv. Nos. M.1/7B1936 and M.1/6.1936). The first of these was uniformly pearlitic, and it was air-cooled for the purpose of hardening. Its average hardness was $268 \mathrm{VPH}$. The other was manufactured from tempered martensite, with an average hardness of 591 VPH (Williams 2003: pp. 704-705).

\section{Metallographic examinations}

A sample was taken from the edge of the couter (Fig. 2a). It was mounted in Electro-Mix electroconductive resin and was ground using $\mathrm{SiC}$ papers $(500,800,1000,1200$, and 2000 
grits). It was then polished with diamond pastes $(6,1$, and $0.5 \mu \mathrm{m}$ ) and etched with $2 \%$ nital for $5 \mathrm{~s}$ in order to reveal its microstructure. Observations were carried out with an OptaTech MM100 inverted metallographic microscope coupled with a $16 \mathrm{mpx}$ digital camera. Hardness tests were carried out with a Wolpert 401MVD hardness tester with a load of $1 \mathrm{kG}$. Zones of detailed observations, microstructures, hardness tests' results, and a technological scheme can be seen in Fig. $2 b$.

On the basis of the examinations, it can be said that the microstructure of the sample is almost entirely ferritic (Figs. $2 \mathrm{c}, \mathrm{f}$, and $3 \mathrm{c}, \mathrm{f}$ ). Only in some places, there is few pearlite in grain boundaries (Figs. 2c-d, 3a, d-e, 4a, c). The overall content of carbon can be assessed at less than $0.1 \% \mathrm{C}$, and it obviously had no influence on functional properties of the metal. Furthermore, it is much too low to render any thermal treatment possible.

In some places on the sample's surface, there are clusters of triangular and rhombic shapes (Figs. $3 b$, e, and $4 b, d$ ). These are so-called etching pits, and they are related to an increased content of $\mathrm{P}$ in the metal. The hardness tests yielded the values of 201.16 and 211.9 HV1 (see Fig. 2b). Such values are pretty high for nearly purely ferritic microstructures, and they seem to confirm the aforementioned observation on the high content of $\mathrm{P}$ in the matrix. According to Thiele and Hošek, such hardness would correspond to the content of $\mathrm{P}$ at the level of c. $0.7-0.8 \mathrm{wt} \%$ (Thiele and Hošek 2015: pp. 122, Fig. 5, 123, Table 2). A strong presence of phosphorus was also demonstrated by etching the surface of the sample with Oberhoffer's reagent. In this case, most of the metallic matrix became relatively bright (as P-rich). Darkening related to $\mathrm{Cu}$ deposition in Ppoor areas could only be seen locally, usually near slag inclusions, which is due to a dephosphorizing effect of slag (Fig. 4e-f) (on this issue, see also, e.g., Piccardo et al. 2004: pp. 650-653; Vega et al. 2003: pp. 338-343, Fig. 2b-c, with examples of similar darkening around slag inclusions). The high content of P may be related to ores used in the smelting process and to the process itself. Furthermore, it rendered any carburisation of the metal impossible.

The metal of the sample contains mono- and multi-phase slag inclusions of various size and shape (oblong or globular) (see Figs. 2c, e-f, 3c-f, and 4a-c). In some cases, their oblong shape is perhaps related to the direction of metal processing. On the other hand, it seems that the overall number of slag inclusions is not too high (about a hundred or so) and the size of individual inclusions is pretty small (for instance, as compared with the metal of a fifteenth-/sixteenth-century gun barrel with many hundreds of slag inclusions, which are sometimes even 50 times larger than those in the metal of the discussed couter, see Żabiński et al. 2019). This implies that the metal underwent many stages of manufacture and was thus quite pure.
It can be said that the couter was manufactured from almost purely ferritic metal (Fig. 2b), which was slowly cooled after fabrication. The raw material was carefully processed and purified which implies a certain level of competence of the manufacturer. On the other hand, the high content of phosphorus (a trait that was beyond control in the discussed period) could have a negative influence on the quality of the artefact and render it rather brittle. It can of course be speculated whether the manufacturer was not able to properly identify the properties of the metal and to select better raw material that would have allowed for carburising and then thermal treatment. It cannot be excluded, either, that better quality iron was not available to him. It is also possible that he may have simply decided that topclass iron was not indispensable in this case, as opposed to such defences as breastplates or helmets which protect more vital parts of the human body.

\section{Analytical approaches in the identification of the iron smelting process}

There are significant differences between the chemical compositions of slag inclusions in iron. What is found as major elements are $\mathrm{Fe}, \mathrm{O}, \mathrm{Si}, \mathrm{Al}, \mathrm{Mg}, \mathrm{Ca}, \mathrm{K}, \mathrm{P}$, and $\mathrm{S}$, with a possible presence of other elements. Minor elements may include Ti, V, $\mathrm{Ba}, \mathrm{Na}$, and others. Although the contents of elements and oxides vary, some regularities can be found. It has been observed that $\mathrm{FeO}$-rich inclusions in most cases occur in the ferritic matrix and inclusions where $\mathrm{SiO}_{2}$ is abundantly present are located in pearlitic zones. This result from the fact that the origin of these inclusions is related to different smelting stages. When the temperature is still low and the reducing power of $\mathrm{CO} / \mathrm{CO}_{2}$ is limited, the ore is reduced to ferritic iron with $\mathrm{FeO}$-rich inclusions. As the temperature and the reducing power of $\mathrm{CO} / \mathrm{CO}_{2}$ increase, metallic phases become carburised, with slag inclusions being poor in $\mathrm{FeO}$ and richer in $\mathrm{SiO}_{2}$. What is more, in many instances ratios between some oxides are more or less steady, for instance, in the case of $\mathrm{MnO} / \mathrm{SiO}_{2}, \mathrm{~K}_{2} \mathrm{O} / \mathrm{Al}_{2} \mathrm{O}_{3}$, or $\mathrm{CaO} / \mathrm{Al}_{2} \mathrm{O}_{3}$ (Buchwald and Wivel 1998: pp. 74-77; Buchwald 2005; id. 2008).

A method of identification of the iron smelting process was proposed by Dillmann and L'Héritier (2007). Its point of departure is an observation that the chemistry of slag inclusions is a function of components of an individual smelting operation and of the process itself. In the bloomery process, the content of the oxides of $\mathrm{Fe}$ and $\mathrm{P}$ in slag inclusions depends on the efficiency of reduction. In the case of the blast furnace process, the metal passes through the liquid stage and pig iron which is obtained is virtually slag-free. Slag inclusions are formed in the finery process stage, and therefore their composition will chiefly depend on refining conditions. There are certain oxides (termed NRCs or non-reduced compound) 
which are not reduced in the course of smelting or become completely reoxidised it the last phase of the process. In order to identify the smelting process, $\mathrm{MgO}, \mathrm{Al}_{2} \mathrm{O}_{3}, \mathrm{SiO}_{2}, \mathrm{~K}_{2} \mathrm{O}$, and $\mathrm{CaO}$ are the most convenient NRCs, as their ratios in smelting-derived slag inclusions are usually constant in iron coming from different manufacturing stages. For this reason, NRC ratios can be perceived as a "signature" of a given smelting system, being an operation implying the use of given ores, fuel, fluxes, and technical ceramics (Dillmann and L'Héritier 2007: p. 1810-1815, Figs. 2-4; L'Héritier et al. 2013: p. 410-412; Disser et al. 2014: p. 316; Blakelock et al. 2009: p. 1747-1748; see also Buchwald 2008; id. 2005, Buchwald and Wivel 1998).
On the other hand, individual slag inclusions may display very different NRC ratios. The chemistry of new inclusions which are formed in subsequent manufacturing stages may be strongly influenced by additives. Thus, their composition will be different from that of smelting-derived inclusions. If a given artefact underwent numerous manufacturing stages (which seems precisely to be the case with the discussed couter), it is almost certain that the chemistry of slag inclusions will be contaminated with additives. What is more, the number of smeltingderived inclusions will very probably be much lower than the number of inclusions related to later stages of manufacture. For this reason, this identification method
Fig. 2 Couter from Ogrodzieniec, Zawiercie District, Upper Silesian Museum in Bytom, MG 7755: (a) spot of sampling; (b) zones of detailed observations,

microstructures $(\mathrm{F}$ - ferrite, $\mathrm{P}$ pearlite, dots mark the presence of carbon), hardness tests' results, and a technological scheme; (c) Zone 1 - ferrite, with locally very low content of pearlite. Oblong and globular slag inclusions can be seen; (d) Zone 1 - traces of pearlite in grain boundaries; (e) Zone 1 - small oblong slag inclusions; (f) Zone 2 - ferrite with slag inclusions of various size and shape

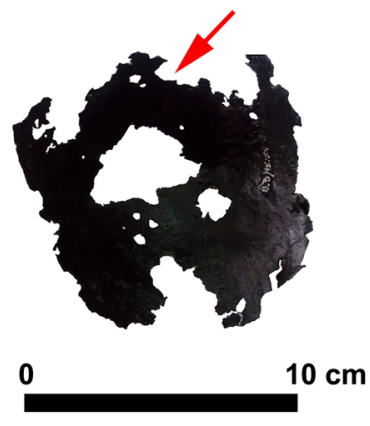

a

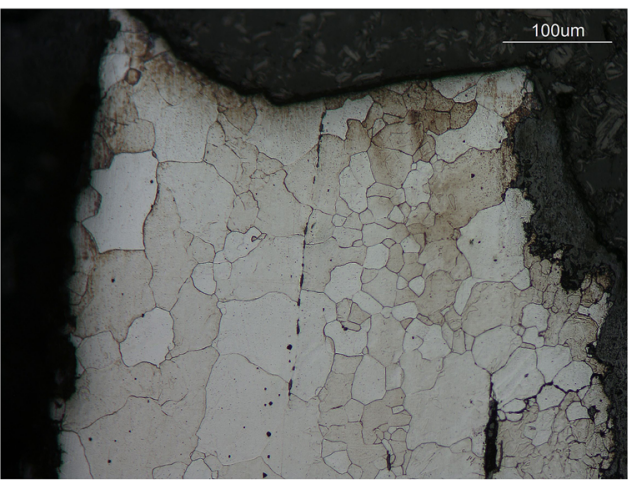

C

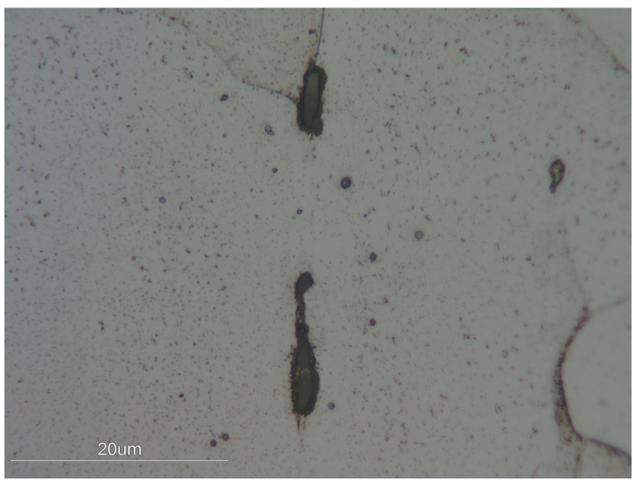

e
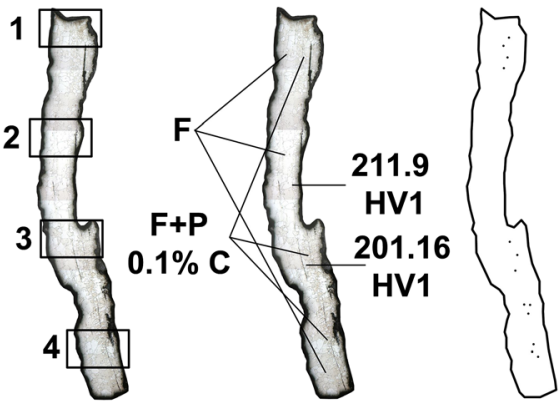

$0.5 \mathrm{~mm}$

b

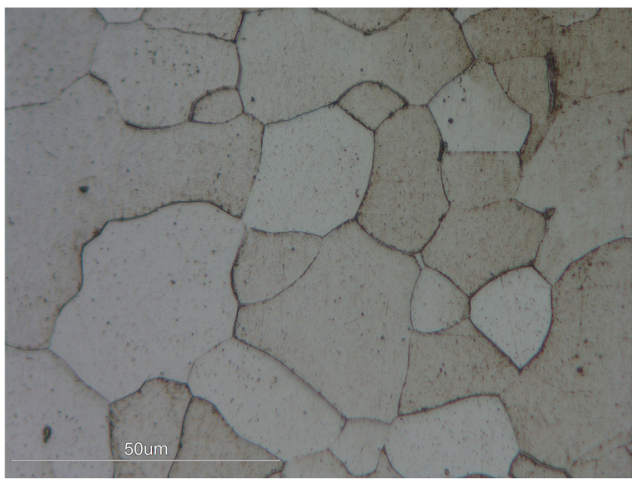

d

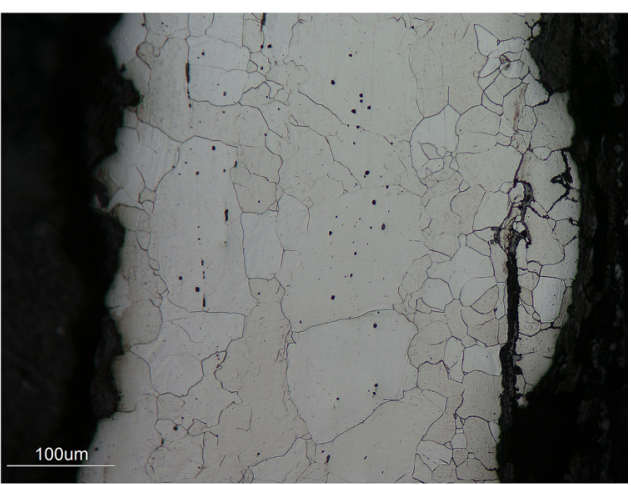

f 
is the most effective for such artefacts which were not too strongly processed (Dillmann and L'Héritier 2007: p. 1814-1815).

The research procedure can be briefly summarised as follows:

- Identifications of zones with varying $\mathrm{C}$ and $\mathrm{P}$ contents and isolation of different pieces of metal (if the artefact is forgewelded). In case there are additive-derived inclusions in welding lines, these are to be examined.

- It is recommended to analyse at least 40 slag inclusions per zone, for the sake of statistical representativeness.

- wt $\%$ of the following oxides are measured: $\mathrm{Na}_{2} \mathrm{O}, \mathrm{MgO}$, $\mathrm{Al}_{2} \mathrm{O}_{3}, \mathrm{SiO}_{2}, \mathrm{P}_{2} \mathrm{O}_{5}, \mathrm{SO}_{3}, \mathrm{~K}_{2} \mathrm{O}, \mathrm{CaO}, \mathrm{TiO}_{2}, \mathrm{Cr}_{2} \mathrm{O}_{3}, \mathrm{~V}_{2} \mathrm{O}_{5}$, $\mathrm{MnO}, \mathrm{FeO}$.
- The composition for each NRC ratio (in most cases, $\% \mathrm{Al}_{2} \mathrm{O}_{3} / \% \mathrm{SiO}_{2}, \% \mathrm{~K}_{2} \mathrm{O} / \% \mathrm{CaO}$, and $\% \mathrm{MgO} / \mathrm{Al}_{2} \mathrm{O}_{3}$ ) is modelled with the use of a linear model passing through 0 . If the determination coefficient $\mathrm{R}^{2}$ is 0.7 or more, a constant ratio can be assumed. If $\mathrm{R}^{2}$ is less than 0.7 , erratic observations are discarded until a reasonable fit is obtained.

- A "surface weighted average composition" is calculated in order to take into consideration not only NRCs but also other elements ( $\mathrm{P}$ and $\mathrm{Fe})$. After the removal of inclusions with abnormal NRC ratios, the "surface weighted average composition" is calculated with the use of all the remaining slag inclusions in a zone. The "weighted content" is a ratio between the surface area of a given slag inclusion and the surface area of all the inclusions which are taken into
Fig. 3 Couter from Ogrodzieniec, Zawiercie District, Upper Silesian Museum in Bytom, MG 7755: (a) Zone 2, ferrite, traces of pearlite are locally present in grain boundaries; (b) Zone 2, rhombic and triangular etching pits, related to the increased content of P; (c) Zone 3, ferrite, several oblong and globular slag inclusions can be seen; (d) Zone 3, ferrite, traces of pearlite in grain boundaries and slag inclusions of various size and shape; (e) Zone 3, cluster of oblong multi-phase slag inclusions, some pearlite is present in grain boundaries; (f) Zone 4, ferrite, oblong and globular slag inclusions can be seen

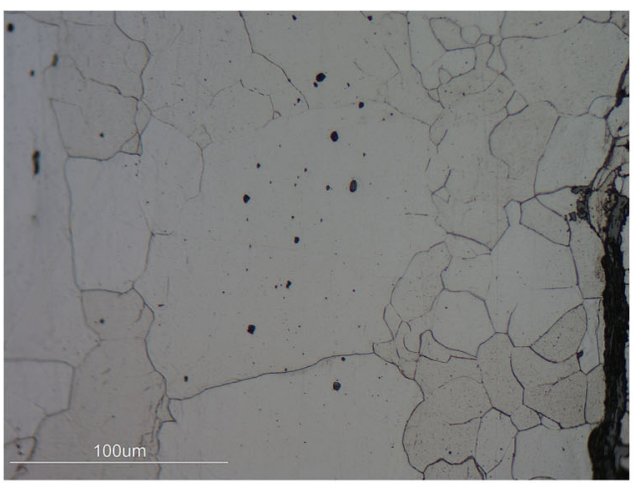

a

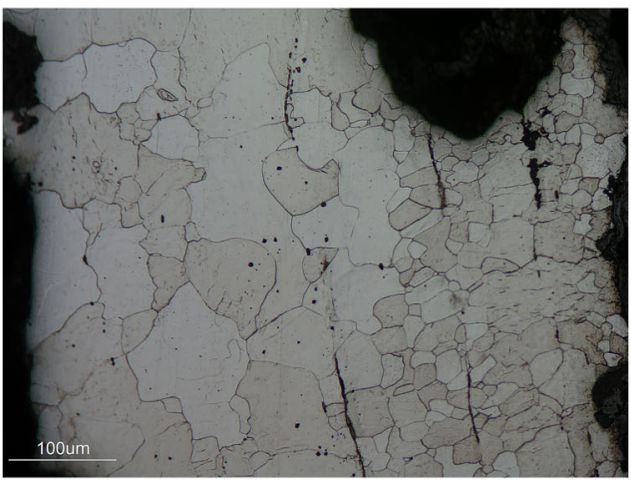

c

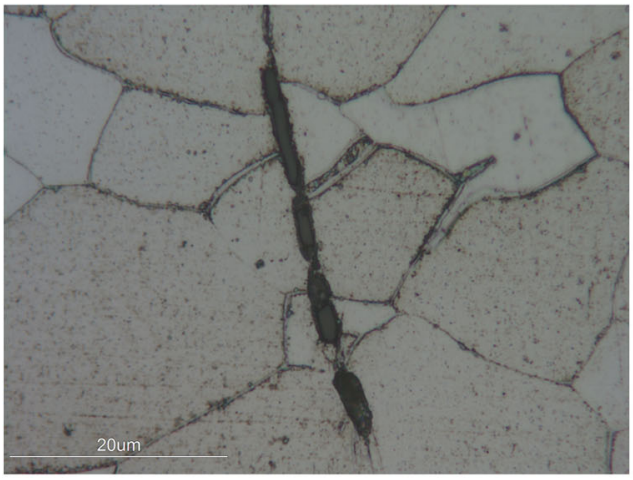

e

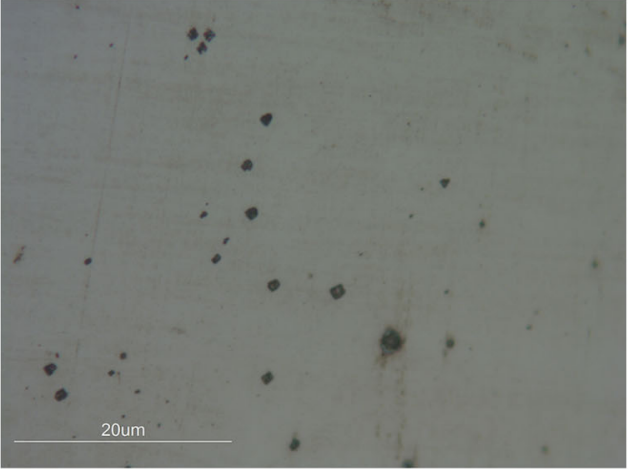

b

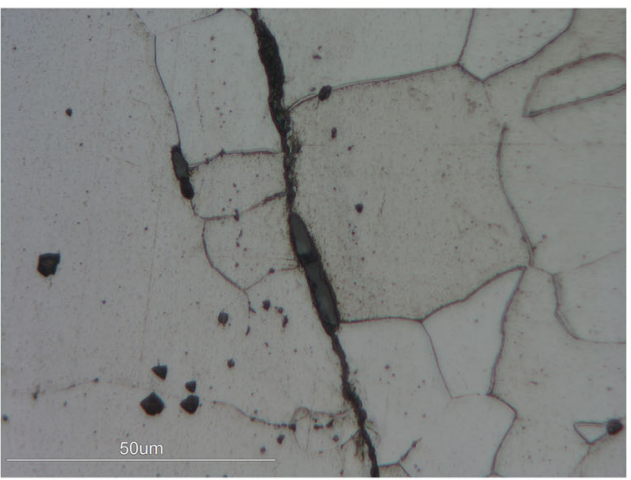

d

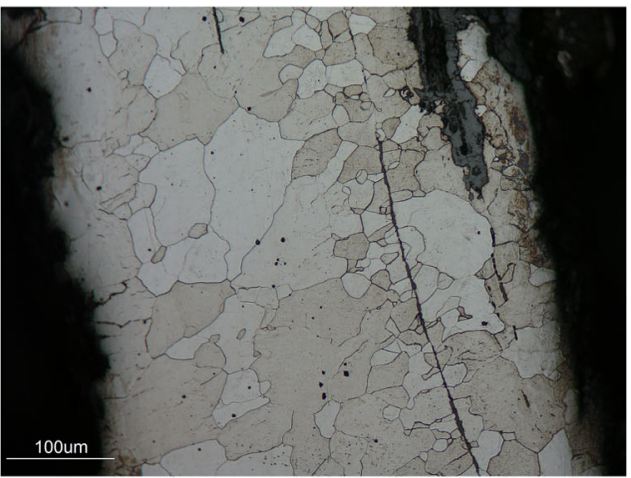

f 
consideration. It is calculated with the use of the following formula (Eq. 1):

$\% E^{*}=\sum_{i=1}^{n}\left(\% E_{i} \times \frac{S_{i}}{S_{T}}\right)$

$\% \mathrm{E}^{*}$ - weighted content of a given element or oxide

$\% \mathrm{E}_{\mathrm{i}}-$ mass content of the element or oxide in the $\mathrm{i}$ slag inclusion (SI)

$\mathrm{S}_{\mathrm{i}}$ - surface of the analysed SI i

$\mathrm{S}_{\mathrm{T}}-$ total surface of all the analysed SI

$\mathrm{n}$ - total number of inclusions

- In order to distinguish between the weighted content and the normal content, the weighted content is marked with an * (e.g., $\% \mathrm{Al}_{2} \mathrm{O}_{3} *$ ). After the elimination of the erratic observations, the NRC ratio shown by linear regression, and the ratio of weighted contents will yield the same results (Dillmann and L'Héritier 2007: p. 1811, 1815-1817; L'Héritier et al. 2013: p. 410-412).

Charlton et al. (2012) developed yet another method of identification of smelting-derived slag inclusions and inclusions related to other manufacturing stages. They assumed that although the approach proposed by Dillmann and L'Héritier performed reasonably, it could lead to a removal of too many inclusions. This could pose a serious problem, especially in the case of artefacts which went through many manufacturing stages and where smeltingderived slag inclusions may be in minority. Therefore, Charlton et al. proposed a method which is based on

Fig. 4 Couter from Ogrodzieniec, Zawiercie District, Upper Silesian Museum in Bytom, MG 7755: (a) Zone 4 , ferrite and slag inclusions, some traces of pearlite in grain boundaries can locally be seen; (b) triangular and rhombic etching pits related to the increased content of P; (c) cluster of oblong multi-phase slag inclusions, some pearlite can be seen in grain boundaries; (d) rhombic etching pits related to the increased content of P; (e) surface of the sample after etching with Oberhoffer's reagent, Zone 1; (f) surface of the sample after etching with Oberhoffer's reagent, Zone 4

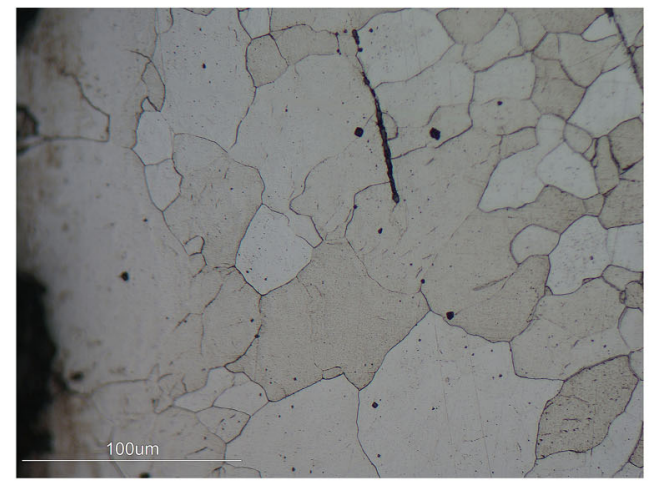

a

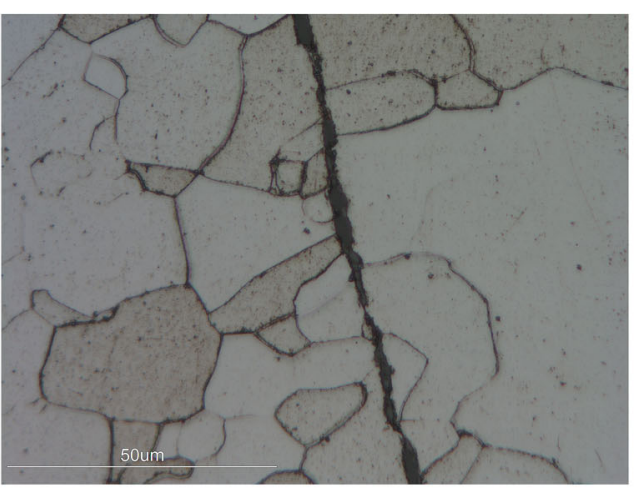

C

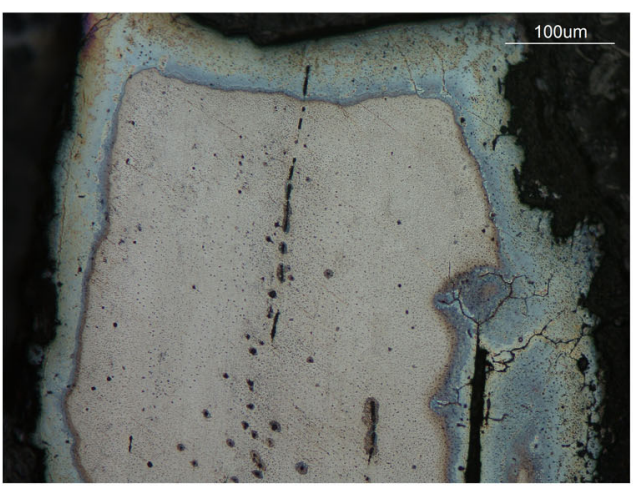

e

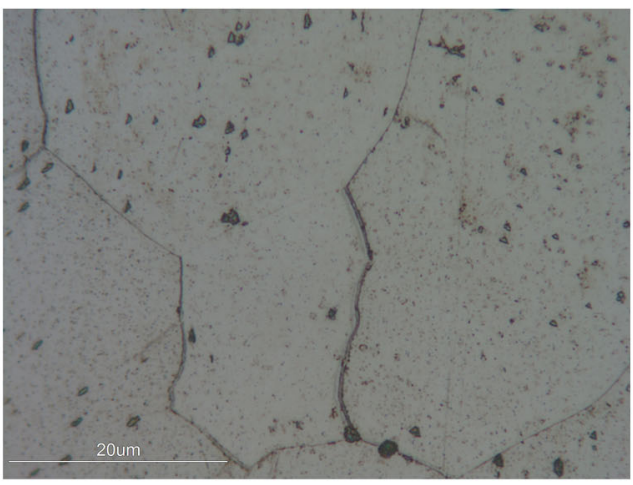

b

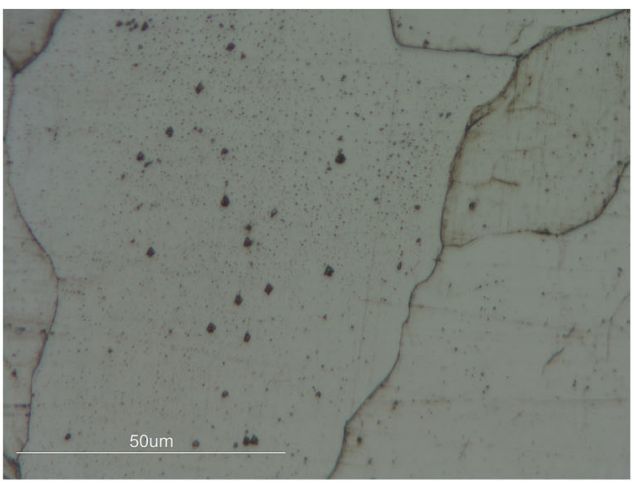

d

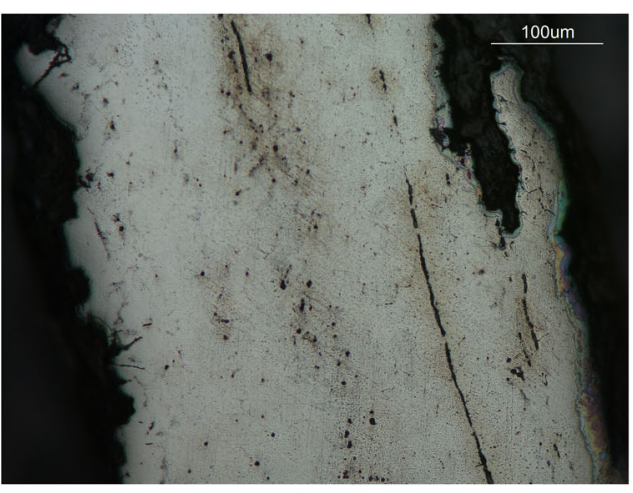

f 
modelling of relationships between the NRCs and the chemistry of their parent materials (Table 1).

These relationships imply that groups of slag inclusions located at the upper extremes of variables with a strong positive correlation come from parent materials whose chemistry is dominated by the same variables (Table 2).

A correlation-type Principal Component Analysis (PCA) is applied in the analysis of these relationships. An obvious advantage of this method is the fact that the greatest part of the variation in a given data assemblage can be represented with the use of the first two or three PC axes. Loadings which express the influence of a variable on a given PC are graphically displayed as vectors which run from the origin of a graph with two PC axes. Individual observations are shown as data points in the $\mathrm{PC}$ space, and their relations to the vectors can be assessed (Charlton et al. 2012: p. 2281-2283). A necessary step prior to the PCA is data transformation in order to cope with the dilution effect from non-modelled compounds and to provide all the variables with a roughly similar weight. Out of many practicable approaches, Charlton et al. used-logged values of subcompositional ratios (i.e., compositions of given oxides divided by the sum of all oxides which are taken into consideration) of NRCs which were included into the analysis (Charlton et al. 2012: p. 2283-2884).

Raw PC scores produced by the PCA are processed with the Agglomerative Hierarchical Clustering (AHC, dissimilarity type, Euclidean distance, and average linkage agglomeration) in order to identify groups of inclusions of different provenance. A dendrogram yielded by the AHC is truncated at the height where the agglomeration rate decreases significantly, albeit it must be remembered that the choice of a proper level may be sometimes arbitrary. Then, obtained clusters are compared with their position on the $\mathrm{PC}$ graph, and the origin of individual clusters (smelting-derived slag inclusions, inclusions related to or contaminated with clay, ash, or flux) is proposed based on their relations to patterns of oxide correlations (see Table 2). Six oxides, that is, $\mathrm{MgO}, \mathrm{Al}_{2} \mathrm{O}_{3}, \mathrm{SiO}_{2}$, $\mathrm{K}_{2} \mathrm{O}, \mathrm{CaO}$, and $\mathrm{TiO}_{2}$, are used in this model. Smelting-derived slag inclusions will plot close to the origin of the graph, as their chemistry is shaped by many parent materials (Charlton et al. 2012: p. 2283-2288, Figs. 1-6; see also Charlton et al. 2013: 422, 425-426). Disser et al. (2014) proposed a modification of this identification method. Only five oxides were taken into consideration (without $\mathrm{TiO}_{2}$ ), the data was transformed using a log-ratio transformation, and the Ward method of agglomeration was used (Disser et al. 2014: p. 322-325; Disser et al. 2017).

According to the method proposed by Dillmann \& L'Héritier, in order to graphically discriminate between the direct and the indirect process, the $\mathrm{x}$ axis of a graph displays the values of $\left(\mathrm{wt} \% \mathrm{Al}_{2} \mathrm{O}_{3} *+\mathrm{wt} \% \mathrm{MgO} *+\mathrm{wt} \% \mathrm{~K}_{2} \mathrm{O}\right) /$ wt $\% \mathrm{FeO}^{*}$ ) and wt $\%$ of $\mathrm{P}_{2} \mathrm{O}_{5} *$ are projected on the y axis. In most cases of slag inclusions in bloomery iron, $\mathrm{x}$ values are high, while y values are low. In the case of blast furnace refined metal, the opposite is true. On the other hand, a "common domain" or an overlapping zone is most likely to occur (Dillmann and L'Héritier 2007: p. 1816-1819, Table 4, Fig. 10; this method was successfully applied in several other works, e.g., Żabiński et al. 2018; Mamani-Calcina et al. 2017; Maia et al. 2015; L'Héritier et al. 2013; 2010; see also Buchwald and Wivel 1998: p. 87-91, Table 4, Fig. 170).

It is also possible to apply so-called weighted contents**, which are oxide weight percents divided by the content of $\mathrm{Fe}$ in the slag inclusions. In this case, what will be shown in the graph is:

$$
\begin{aligned}
\mathrm{y} \text { axis }: & \mathrm{wt} \% \mathrm{P}_{2} \mathrm{O}_{5} * * \\
& =100 \\
\times & \left(\mathrm{P}_{2} \mathrm{O}_{5} *\right) /((\text { AllOxides } *)-\mathrm{FeO} *) \\
\mathrm{x} \text { axis : } & \left(\mathrm{wt} \% \mathrm{Al}_{2} \mathrm{O}_{3} * *+\mathrm{wt} \% \mathrm{MgO} * *+\mathrm{wt} \% \mathrm{~K}_{2} \mathrm{O} * *\right) \\
= & \left(100 \times\left(\mathrm{Al}_{2} \mathrm{O}_{3} *\right) /((\text { AllOxides } *)-\mathrm{FeO} *)\right) \\
& +\left(100 \times\left(\mathrm{MgO}^{*}\right) /((\text { AllOxides } *)-\mathrm{FeO} *)\right) \\
& +\left(100 \times\left(\mathrm{K}_{2} \mathrm{O} *\right) /\left((\text { AllOxides } *)-\mathrm{FeO}^{*}\right)\right)
\end{aligned}
$$

The final principle of discrimination between both smelting processes is identical. Bloomery slag inclusions should display high $\mathrm{x}$ values and low y values, while the reverse will be the case with inclusions in blast furnace refined iron (Dr Maxime L'Héritier, personal communication, 9 June 2017; see also Disser et al. 2014: p. 325).

Yet another method of identification of the smelting process was developed by Disser et al. (2014). In the identification of smelting-derived slag inclusions, these researchers followed the log-ratio approach for the purpose of data transformation. The following calculation was done for each slag inclusion (Eq. 4):

$\left.X i_{\mathrm{NRC}}=\log \left(E i_{\mathrm{NRC}}\right)-g\left(\log E_{\mathrm{NRC}}\right)\right)$

$i-$ individual slag inclusion

$X i_{\mathrm{NRC}}$ - transformed value for each NRC $\left(\mathrm{MgO}, \mathrm{Al}_{2} \mathrm{O}_{3}\right.$, $\mathrm{SiO}_{2}, \mathrm{~K}_{2} \mathrm{O}, \mathrm{CaO}$ )

$E i_{\mathrm{NRC}}-\mathrm{NRC}$ amount in a given slag inclusion

$g\left(\log E_{\mathrm{NRC}}\right)-$ geometrical mean of $\log$ of NRCs

The next step in the identification of smelting-derived inclusions was the PCA and the AHC (see above). What is

Table 1 Relationships between NRCs and the chemistry of their parent materials (after Charlton et al. 2012, p. 2283, Table 1)

\begin{tabular}{lllllllll}
\hline & $\mathrm{MgO}$ & $\mathrm{Al}_{2} \mathrm{O}_{3}$ & $\mathrm{SiO}_{2}$ & $\mathrm{~K}_{2} \mathrm{O}$ & $\mathrm{CaO}$ & $\mathrm{TiO}_{2}$ & $\mathrm{SrO}$ & $\mathrm{BaO}$ \\
\hline Bloomery slag & $*$ & $*$ & $*$ & $*$ & $*$ & $*$ & $*$ & $*$ \\
Clay & & $*$ & $*$ & $*$ & & $*$ & & $*$ \\
Fuel ash & $*$ & & & $*$ & $*$ & & $*$ & \\
Smithing flux & & & $*$ & & & & & \\
\hline
\end{tabular}


Table 2 Provenance of slag inclusions located at upper extremes of NRC pairs with strong positive correlations (LC - localised concentration ef fect) (after Charlton et al. 2012, p. 2283, Table 2)

\begin{tabular}{lllllllll}
\hline & $\mathrm{MgO}$ & $\mathrm{Al}_{2} \mathrm{O}_{3}$ & $\mathrm{SiO}_{2}$ & $\mathrm{~K}_{2} \mathrm{O}$ & $\mathrm{CaO}$ & $\mathrm{TiO}_{2}$ & $\mathrm{SrO}$ & $\mathrm{BaO}$ \\
\hline $\mathrm{MgO}$ & LC/ash & & & Ash & Ash & & Ash & \\
$\mathrm{Al}_{2} \mathrm{O}_{3}$ & & LC/clay & Clay & Clay & & Clay & & Clay \\
$\mathrm{SiO}_{2}$ & & Clay & LC/flux & Clay & & Clay & & Clay \\
$\mathrm{K}_{2} \mathrm{O}$ & Ash & Clay & Clay & LC/ash/clay & Ash & Clay & Ash & Clay \\
$\mathrm{CaO}$ & Ash & & & Ash & LC/ash & & Ash & \\
$\mathrm{TiO}_{2}$ & & Clay & Clay & Clay & & LC/clay & & Clay \\
$\mathrm{SrO}$ & Ash & & & Ash & Ash & & LC/ash & \\
$\mathrm{BaO}$ & & Clay & Clay & Clay & & Clay & & LC/clay \\
\hline
\end{tabular}

important, the correctness of selection and of identification of slag groups of a given provenance was eventually verified by plotting the NRC contents on bivariate graphs and by observing whether a linear behaviour could be seen in a majority of cases (which is in line with what was proposed by Dillmann and L'Héritier 2007) (Disser et al. 2014: p. 322-326, Figs. 610). A potential data distortion in the form of overrepresentation of Fe due to the matrix effect was overcome by means of calculating a subcompositional ratio for each oxide (Eq. 5):

$\%$ oxide $* *=(\%$ oxide $* \times 100) /\left(100-\mathrm{FeO}^{*}\right)$

In order to distinguish between both smelting processes, attention was paid to different patterns of behaviour displayed by certain oxides. $\mathrm{MgO}, \mathrm{Al}_{2} \mathrm{O}_{3}$, and $\mathrm{K}_{2} \mathrm{O}$ are not reduced either in the direct or in the indirect process. In the bloomery process, these oxides can be abundantly found both in slag and in slag inclusions in iron. In contrast to that, in the blast furnace process, these oxides pass into the slag and thus leave the smelting operation. Therefore, slag inclusions which come into existence during the refining stage display much lower concentrations of these NRCs. On the other hand, oxides of P undergo a partial reduction in cast iron and form phosphorus eutectics in it. For this reason, slag inclusions formed in the course of the refining stage will demonstrate high contents of $\mathrm{P}_{2} \mathrm{O}_{5}$. What is more, different behavioural patterns in both processes were also observed for $\mathrm{SiO}_{2}, \mathrm{CaO}$, and $\mathrm{MnO}$ which suggests that these oxides should also be considered in the identification model (Disser et al. 2014: p. 325).

The model itself is based on the method of logistic regression. In the classical multivariate linear regression analysis, there is a quantitative variable $Y$ with several possible explanatory variables $\left(X^{1}, X^{2} \ldots, X^{n}\right)$ and $Y$ is a linear combination of $X^{i}$. This can be expressed with the following equation:

$Y=\beta^{0}+\beta^{l} X^{l}+\beta^{2} X^{2} \ldots \beta^{n} X^{n}$

The $\left(\beta^{l}, \beta^{2}, \ldots \beta^{n}\right)$ are coefficients which correspond to the relative contribution of respective variables to the prediction of $Y$. Maximum likelihood can be used to estimate the $\left(\beta^{l}, \beta^{2}\right.$, $\left.\ldots \beta^{n}\right)$ for assemblages of identified $\left(Y_{i}\right)$ with their $\left(\mathrm{X}_{i}^{1}, X_{i}^{2} \ldots X_{i}^{n}\right)$ variables. In the next step, new outcomes $\left(Y_{j}\right)$ can be predicted from new assemblages of variables $\left(\mathrm{X}_{j}^{1}, X_{j}^{2} \ldots X_{j}^{n}\right)$ and the estimated coefficients. As in this case, the $Y$ is binary (the process is either bloomery or blast furnace), multivariate logistic regression can be used in place of linear regression. A linear combination of variables $\left(\mathrm{X}_{j}^{1}, X_{j}^{2} \ldots X_{j}^{n}\right)$ models the Logit $(p)$, where $p$ is the probability of $Y=1$ and Logit $(p)=\log (p / 1-p)$ is a continuous variable between $-\infty$ and $+\infty$. The logistic regression model is expressed as:

$\operatorname{Logit}(p)=\beta^{0}+\beta^{l} X^{1}+\beta^{2} X^{2} \ldots \beta^{n} X^{n}$

Maximum likelihood method is used in the estimation of the $\left(\beta^{l}, \beta^{2}, \ldots \beta^{n}\right)$ coefficients. For this purpose, one uses assemblages $\left(\mathrm{X}_{i}^{1}, X_{i}^{2} \ldots X_{i}^{n}\right)$ with a known $Y$ value being 0 or 1. New variable assemblages $\left(\mathrm{X}_{j}^{1}, X_{j}^{2} \ldots X_{j}^{n}\right)$ are evaluated, and $\operatorname{Logit}(p)=\beta^{0}+\beta^{l} X^{l}+\beta^{2} X^{2} \ldots \beta^{n} X^{n}$ predicts the probability $p$ (Disser et al. 2014: p. 325-326). As $Y=0$ for the bloomery process, while $Y=1$ for the blast furnace process, the final equation is of the following shape (Eq. 6):

$$
\begin{aligned}
\operatorname{Logit}(p)= & \beta^{0}+\beta^{M g}[\% \mathrm{MgO} * *]+\beta^{A l}\left[\% \mathrm{Al}_{2} \mathrm{O}_{3} * *\right] \\
& +\beta^{S i}\left[\% \mathrm{SiO}_{2} * *\right]+\beta^{P}\left[\% \mathrm{P}_{2} \mathrm{O}_{5} * *\right] \\
& +\beta^{K}\left[\% \mathrm{~K}_{2} \mathrm{O} * *\right]+\beta^{C a}[\% \mathrm{CaO} * *] \\
& +\beta^{M n}[\% \mathrm{MnO} * *]
\end{aligned}
$$

Table 3 Logistic regression parameters calculated on the basis of the reference set (138 samples) (after Disser et al. 2014: p. 328, Table 5)

\begin{tabular}{llcl}
\hline Oxide** & Parameter & Value & Std. error \\
\hline Intercept & $B^{0}$ & 5.22 & 3.320 \\
$\mathrm{MgO}$ & $\beta^{M g}$ & 0.13 & 0.35 \\
$\mathrm{Al}_{2} \mathrm{O}_{3}$ & $\beta^{4 l}$ & -0.95 & 0.25 \\
$\mathrm{SiO}_{2}$ & $\beta^{S i}$ & 0.007 & 0.043 \\
$\mathrm{P}_{2} \mathrm{O}_{5}$ & $\beta^{P}$ & 0.16 & 0.065 \\
$\mathrm{~K}_{2} \mathrm{O}$ & $\beta^{K}$ & -0.84 & 0.44 \\
$\mathrm{CaO}$ & $\beta^{C a}$ & 0.088 & 0.058 \\
$\mathrm{MnO}$ & $\beta^{M n}$ & 0.018 & 0.091 \\
\hline
\end{tabular}


Table 4 Couter from Ogrodzieniec, Zawiercie District, Upper Silesian Museum in Bytom, MG 7755: results of SEM-EDS examinations of the chemical composition of slag inclusions (wt\%)

\begin{tabular}{|c|c|c|c|c|c|c|c|c|c|c|c|c|}
\hline & $\mathrm{MgO}$ & $\mathrm{Al}_{2} \mathrm{O}_{3}$ & $\mathrm{SiO}_{2}$ & $\mathrm{P}_{2} \mathrm{O}_{5}$ & $\mathrm{~K}_{2} \mathrm{O}$ & $\mathrm{CaO}$ & $\mathrm{TiO}_{2}$ & $\mathrm{MnO}$ & $\mathrm{FeO}$ & $\mathrm{SO}_{3}$ & $\mathrm{Na}_{2} \mathrm{O}$ & Total \\
\hline SI10 & 0.49 & 0.73 & 13.83 & 7.97 & 0.24 & 0.38 & 0.43 & 0.37 & 75.29 & 0.17 & 0.09 & 100.00 \\
\hline SI11 & 0.26 & 0.31 & 12.34 & 2.72 & 0.16 & 2.79 & 0.32 & 0.28 & 80.32 & 0.26 & 0.24 & 100.00 \\
\hline SI12 & 0.16 & 0.29 & 16.51 & 0.64 & 0.11 & 1.04 & 0.32 & 0.25 & 80.23 & 0.23 & 0.21 & 100.00 \\
\hline SI13 & 0.37 & 0.35 & 6.04 & 7.72 & 0.26 & 0.42 & 0.38 & 0.34 & 83.51 & 0.42 & 0.20 & 100.00 \\
\hline SI14 & 0.41 & 0.28 & 33.47 & 1.38 & 0.12 & 0.22 & 0.32 & 0.45 & 63.11 & 0.08 & 0.15 & 100.00 \\
\hline SI15 & 0.28 & 0.27 & 30.71 & 1.22 & 0.15 & 0.42 & 0.40 & 0.22 & 65.76 & 0.42 & 0.14 & 100.00 \\
\hline SI16 & 0.31 & 0.21 & 32.24 & 1.56 & 0.17 & 0.39 & 0.44 & 0.33 & 63.87 & 0.29 & 0.21 & 100.00 \\
\hline SI17 & 0.30 & 0.29 & 20.36 & 5.19 & 0.14 & 0.30 & 0.30 & 0.22 & 72.62 & 0.09 & 0.18 & 100.00 \\
\hline SI19 & 0.32 & 0.59 & 17.89 & 8.69 & 0.20 & 0.35 & 0.41 & 0.19 & 71.07 & 0.05 & 0.24 & 100.00 \\
\hline SI20 & 0.91 & 0.32 & 32.76 & 0.76 & 0.12 & 0.32 & 0.34 & 0.35 & 63.76 & 0.19 & 0.17 & 100.00 \\
\hline SI21 & 0.46 & 13.15 & 23.44 & 1.47 & 0.18 & 0.49 & 0.45 & 0.37 & 59.55 & 0.32 & 0.11 & 100.00 \\
\hline SI22 & 0.51 & 5.07 & 25.17 & 7.26 & 1.41 & 0.99 & 0.46 & 0.30 & 58.66 & 0.04 & 0.12 & 100.00 \\
\hline SI23 & 0.24 & 0.37 & 17.64 & 1.01 & 0.21 & 0.53 & 0.32 & 0.24 & 79.07 & 0.28 & 0.08 & 100.00 \\
\hline SI24 & 0.36 & 0.54 & 14.74 & 4.38 & 0.12 & 0.29 & 0.32 & 0.37 & 78.57 & 0.07 & 0.23 & 100.00 \\
\hline SI25 & 0.26 & 0.37 & 14.31 & 23.05 & 0.89 & 0.65 & 0.32 & 0.34 & 59.40 & 0.24 & 0.17 & 100.00 \\
\hline
\end{tabular}

A set of 138 samples for which the smelting process is known was used in the calculation of the eight coefficients $\left(\beta^{0}+\beta^{M g}+\beta^{A l}+\beta^{S i}+\beta^{P}+\beta^{K}+\beta^{C a}+\beta^{M n}\right)$. A Bayesian optimisation algorithm-based numerical iterative approach was applied in the estimation of the maximum likelihood. Probabilities for the blast furnace $(p)$ or the bloomery (1-p) process can also be calculated. The process with the highest predicted probability corresponds to the known process, with $p>0.5$ for all blast furnace samples and $p<0.5$ for bloomery iron
Table 5 Couter from Ogrodzieniec, Zawiercie District, Upper Silesian Museum in Bytom, MG 7755: ratios of selected oxides and their $\mathrm{R}^{2}$ determination coefficients

\begin{tabular}{|c|c|c|c|c|c|c|c|}
\hline & $\mathrm{Al}_{2} \mathrm{O}_{3} / \mathrm{SiO}_{2}$ & $\begin{array}{l}\mathrm{K}_{2} \mathrm{O} / \\
\mathrm{CaO}\end{array}$ & $\begin{array}{l}\mathrm{MgO} / \\
\mathrm{Al}_{2} \mathrm{O}_{3}\end{array}$ & $\begin{array}{l}\mathrm{Al}_{2} \mathrm{O}_{3} / \\
\mathrm{CaO}\end{array}$ & $\begin{array}{l}\mathrm{K}_{2} \mathrm{O} / \\
\mathrm{MgO}\end{array}$ & $\begin{array}{l}\mathrm{SiO}_{2} / \\
\mathrm{MgO}\end{array}$ & $\begin{array}{l}\mathrm{Al}_{2} \mathrm{O}_{3} / \\
\mathrm{K}_{2} \mathrm{O}\end{array}$ \\
\hline SI10 & 0.053 & 0.639 & 0.669 & 1.921 & 0.497 & 28.187 & 3.007 \\
\hline SI11 & 0.026 & 0.058 & 0.821 & 0.113 & 0.627 & 47.719 & 1.943 \\
\hline SI12 & 0.017 & 0.111 & 0.541 & 0.277 & 0.739 & 106.145 & 2.501 \\
\hline SI13 & 0.057 & 0.631 & 1.060 & 0.827 & 0.720 & 16.454 & 1.310 \\
\hline SI14 & 0.008 & 0.553 & 1.454 & 1.321 & 0.288 & 81.040 & 2.389 \\
\hline SI15 & 0.009 & 0.361 & 1.062 & 0.632 & 0.538 & 109.072 & 1.751 \\
\hline SI16 & 0.006 & 0.425 & 1.506 & 0.530 & 0.533 & 103.394 & 1.245 \\
\hline SI17 & 0.014 & 0.448 & 1.036 & 0.969 & 0.446 & 66.867 & 2.162 \\
\hline SI19 & 0.033 & 0.576 & 0.550 & 1.713 & 0.612 & 55.059 & 2.973 \\
\hline SI20 & 0.010 & 0.383 & 2.874 & 0.971 & 0.137 & 36.162 & 2.535 \\
\hline SI21 & 0.561 & 0.378 & 0.035 & 27.109 & 0.395 & 50.445 & 71.717 \\
\hline SI22 & 0.201 & 1.423 & 0.101 & 5.098 & 2.754 & 49.001 & 3.582 \\
\hline SI23 & 0.021 & 0.386 & 0.653 & 0.694 & 0.852 & 72.972 & 1.796 \\
\hline SI24 & 0.037 & 0.420 & 0.657 & 1.844 & 0.347 & 41.473 & 4.392 \\
\hline SI25 & 0.026 & 1.362 & 0.714 & 0.565 & 3.378 & 54.445 & 0.415 \\
\hline \multicolumn{8}{|c|}{$\mathrm{R}^{2}$ for $\mathrm{Al}_{2} \mathrm{O}_{3} / \mathrm{SiO}_{2}:-5.016$} \\
\hline \multicolumn{8}{|c|}{$\mathrm{R}^{2}$ for $\mathrm{K}_{2} \mathrm{O} / \mathrm{CaO}:-0.469$} \\
\hline \multicolumn{8}{|c|}{$\mathrm{R}^{2}$ for $\mathrm{MgO} / \mathrm{Al}_{2} \mathrm{O}_{3}: 0.045$} \\
\hline \multicolumn{8}{|c|}{$\mathrm{R}^{2}$ for $\mathrm{Al}_{2} \mathrm{O}_{3} / \mathrm{CaO}:-0.884$} \\
\hline \multicolumn{8}{|c|}{$\mathrm{R}^{2}$ for $\mathrm{K}_{2} \mathrm{O} / \mathrm{MgO}:-2.607$} \\
\hline \multicolumn{8}{|c|}{$\mathrm{R}^{2}$ for $\mathrm{SiO}_{2} / \mathrm{MgO}:-0.011$} \\
\hline \multicolumn{8}{|c|}{$\mathrm{R}^{2}$ for $\mathrm{Al}_{2} \mathrm{O}_{3} / \mathrm{K}_{2} \mathrm{O}:-0.422$} \\
\hline
\end{tabular}


Table 6 Couter from Ogrodzieniec, Zawiercie District, Upper Silesian Museum in Bytom, MG 7755: subcompositional ratios and their-log values of selected oxides in slag inclusions

\begin{tabular}{|c|c|c|c|c|c|c|c|c|c|c|c|c|c|c|c|c|c|c|}
\hline \multirow[b]{2}{*}{ SI/Obs. } & \multirow[b]{2}{*}{$\mathrm{MgO}$} & \multirow[b]{2}{*}{$\mathrm{Al}_{2} \mathrm{O}_{3}$} & \multirow[b]{2}{*}{$\mathrm{SiO}_{2}$} & \multirow[b]{2}{*}{$\mathrm{K}_{2} \mathrm{O}$} & \multirow[b]{2}{*}{$\mathrm{CaO}$} & \multirow[b]{2}{*}{$\mathrm{TiO}_{2}$} & \multicolumn{6}{|c|}{ Subcompositional ratios } & \multicolumn{6}{|c|}{$\begin{array}{l}\text { Subcompositional ratios' -logged } \\
\text { (log-base 10) values }\end{array}$} \\
\hline & & & & & & & $\mathrm{gO}$ & $\mathrm{Al}_{2} \mathrm{O}_{3}$ & $\mathrm{SiO}_{2}$ & $\mathrm{~K}_{2} \mathrm{O}$ & $\mathrm{aO}$ & $\mathrm{TiO}_{2}$ & $\mathrm{O}$ & $\mathrm{Al}_{2} \mathrm{O}_{3}$ & $\mathrm{SiO}_{2}$ & $\mathrm{~K}_{2} \mathrm{O}$ & $\mathrm{CaO}$ & $\mathrm{Ti}$ \\
\hline $10 / 1$ & 491 & 0.733 & 3.827 & 244 & & 429 & 0.030 & 0.046 & 0.859 & 0.015 & 0.024 & & 52 & 1.34 & 0.07 & 1.82 & 1.63 & 1.5 \\
\hline $\mathrm{SI} 11 / 2$ & 0.259 & 0.315 & 2.336 & 162 & 2.794 & 0.322 & 0.016 & 0.019 & 0.762 & 0.010 & 0.173 & 0.020 & 30 & 1.71 & 0.12 & 2.00 & 0.76 & 1.70 \\
\hline $112 / 3$ & 156 & 87 & 16.507 & 115 & 1.038 & 0.324 & 0.008 & 0.016 & 0.896 & 0.006 & 0.056 & 0.018 & 7 & 1.81 & 0.05 & 2.21 & 1.25 & 1.7 \\
\hline & 7 & & & & & & 17 & & 0.772 & & & & 3 & & & 47 & 1.27 & 1.31 \\
\hline & 3 & & & & & & 0.012 & & & & & & & - & 0.02 & 2.47 & 2.21 & 2.04 \\
\hline SI15/6 & 0.282 & 0.265 & 30.707 & & 0.420 & & 0.009 & 0.008 & 0.953 & 0.005 & 0.013 & 0.012 & 2.06 & 2.08 & 0.02 & 2.33 & 1.89 & 1.91 \\
\hline SI16/7 & 0.312 & & 32.240 & & 0.391 & 0.437 & 0.009 & 0.006 & 0.955 & 0.005 & 0.012 & & 2.03 & 2.21 & 0.02 & 2.31 & 1.94 & 1.89 \\
\hline SI17/8 & 0.305 & 0.294 & 20.364 & & 0.303 & 0.298 & 0.014 & 0.014 & 0.938 & 0.006 & 0.014 & 0.014 & 1.85 & 1.87 & 0.03 & 2.20 & 1.85 & 1.86 \\
\hline SI19/9 & 0.325 & 0.591 & 17.887 & 0.199 & 0.345 & 0.408 & 0.016 & 0.030 & 0.905 & 0.010 & 0.017 & 0.021 & 1.78 & 1.52 & 0.04 & 2.00 & 1.76 & 1.68 \\
\hline SI20/10 & 0.906 & 0.315 & 32.762 & & 0.325 & 0.343 & 0.026 & 0.009 & 0.942 & 0.004 & 0.009 & 0.010 & 1.58 & 2.04 & 0.03 & 2.45 & 2.03 & 2.01 \\
\hline SI21/11 & 0.465 & 13.155 & 23.443 & 0.183 & 0.485 & 0.455 & 0.012 & 0.344 & 0.614 & 0.005 & 0.013 & 0.012 & 1.91 & 0.46 & 0.21 & 2.32 & 1.90 & 1.92 \\
\hline SI22/12 & 0.514 & 5.067 & 25.168 & 1.415 & 0.994 & 0.457 & 0.015 & 0.151 & 0.749 & 0.042 & 0.030 & 0.014 & 1.82 & 0.82 & 0.13 & 1.38 & 1.53 & 1.8 \\
\hline SI23/13 & 0.242 & 0.370 & 17.639 & 0.206 & 0.534 & 0.321 & 0.013 & 0.019 & 0.913 & 0.011 & 0.028 & 0.017 & 1.90 & 1.72 & 0.04 & 1.97 & 1.56 & 1.7 \\
\hline SI24/14 & 0.356 & 0.542 & 14.744 & 0.123 & 0.294 & 0.322 & 0.022 & 0.033 & 0.900 & 0.008 & 0.018 & 0.020 & 1.66 & 1.48 & 0.05 & 2.12 & 1.75 & 1.7 \\
\hline SI25/15 & 0.263 & 0.368 & 14.314 & 0.888 & 0.652 & 0.318 & 0.016 & 0.022 & 0.852 & 0.053 & 0.039 & 0.019 & 1.81 & 1.66 & 0.07 & 1.28 & 1.41 & 1.72 \\
\hline
\end{tabular}

samples. Probabilities for any other sample can be calculated with the use of the logit parameters (see Table 3) (Disser et al. 2014: p. 326-328, Table 5).

A total of 61 new samples of construction iron were examined with the use of this method. In the assemblage of 18 samples from Beauvais Cathedral, 16 were assessed as bloomery iron, while 2 were not determined. Regarding 43 samples from Metz Cathedral, 11 turned out to be bloomery metal, 28 were blast furnace refined iron, and 2 were not determined. Generally, the Logit $(p)$ turned out to be between 1.95 and 8.30 in the case of the blast furnace process, while in the case of the bloomery process, the values were between 18.26 and - 2.32 (Disser et al. 2014: p. 328-329, Tables 7-8, Fig. 13).

\section{Attempt at identification of the iron smelting process}

Due to technical reasons, analyses of slag inclusions were held in three institutions: the Institute of Materials Science of the Silesian University in Katowice, the Faculty of Mathematics and Natural Science of the Jan Długosz University in Czesstochowa, and in the National Centre for Nuclear Research in Świerk. The following equipment was used respectively: a JEOL JSM-6480 scanning microscope with an EDS analyser, a Vega3 Tescan scanning microscope with an $\mathrm{X}$-act 51-ADD-000-7 Penta Fet Precision EDS analyser, as well as a Carl Zeiss EVO MA 10 scanning microscope with an EDX Bruker Quantax spectrometer. In all the analyses, a result for each slag inclusion is an average of several measurements in different zones. As there were no significant differences between results yielded by different instruments, all analyses were taken into consideration. Data was processed in Excel, and all calculations were done in Xlstat-R software (Version 2018.7). The main objective of the analyses was to obtain data that could be used in the identification of the smelting process - bloomery (direct) or blast furnace (indirect). Although, as stated above, it is believed that blast furnace refined iron first went into use for the manufacture of armour in the early sixteenth century, the very process is of a much earlier (possibly twelfth century) date (see, e.g., Buchwald and Wivel 1998: pp. 87-92; Buchwald 2005: pp. 336-340; id.: 2008; Williams 2003: pp. 879-886; Williams 2012: pp. 187-201). Therefore, a possibility that the discussed couter was manufactured from such metal should not be completely ruled out.

What follows below seems to be a very good example of difficulties that may be encountered when trying to analyse slag inclusions in ferrous artefacts which underwent many stages of manufacture. It was possible to analyse the composition of 43 slag inclusions altogether, but it must be openly said that hardly any more that would be of proper size could be found. Furthermore, in a majority of cases, these were FeOdominated wüstite inclusions, where many oxides which are relevant for the isolation of smelting-derived slag inclusions and for the identification of the smelting process were absent or below detection limits. Therefore, these observations were 
Fig. 5 Couter from Ogrodzieniec, Zawiercie District, Upper Silesian Museum in Bytom, MG 7755: identification of smelting-derived slag inclusions with the Principal Component Analysis (top), and the Agglomerative Hierarchical Clustering (dissimilarity type, Euclidean distance, weighted pair-group average agglomeration) (bottom)
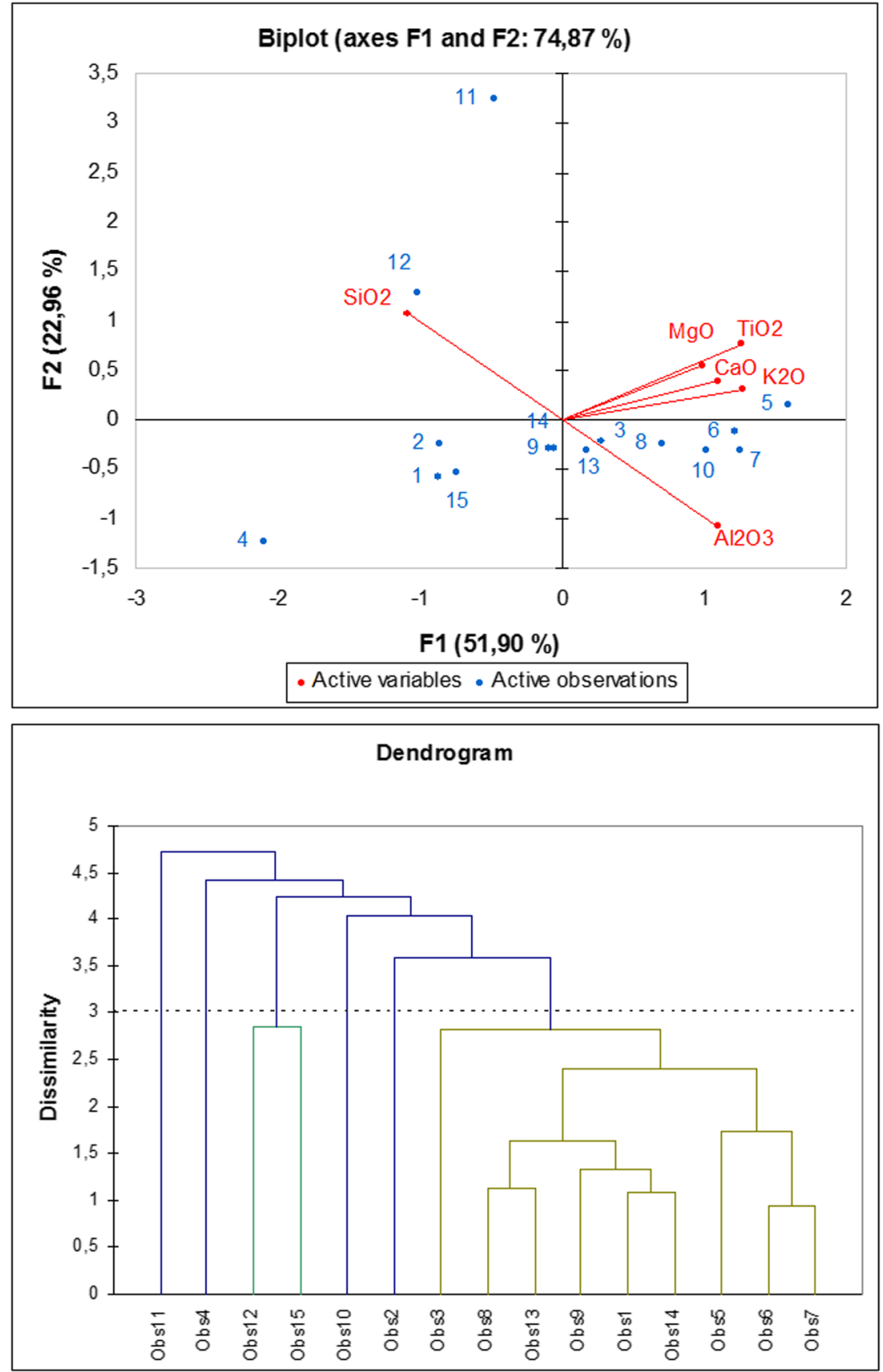

to be discarded in the initial stage of research (these problems were also evocated in Buchwald and Wivel 1998: pp. 93-94). What remained were 15 slag inclusions whose chemistry can be found in Table 4.

In order to isolate smelting-derived slag inclusions, a combination of the methods which were discussed above was applied. First, selected ratios of oxides and their $\mathrm{R}^{2}$ determination coefficients were calculated (Table 5).

The determination coefficients clearly demonstrate that the behaviour of all the relevant oxides is extremely erratic and a selection of smelting-derived inclusions solely on the basis of this approach would be enormously difficult. It was therefore decided to use the method proposed by Charlton et al. (2012); however, following the advice evocated in Disser et al. (2014), this method was combined with the $\mathrm{R}^{2}$-based verification. Table 6 offers results of calculations of oxide subcompositional ratios and their -log values.

In the next step, the obtained -log values were processed with the Principal Component Analysis and raw PC scores were analysed with the Agglomerative Hierarchical Clustering (dissimilarity type, Euclidean distance, weighted pair-group average agglomeration). The position of numerous observations on the PC graph and their assignment to classes (Fig. 5) might imply that they could be considered as 
Table $7 \quad \mathrm{R}^{2}$ determination coefficients for selected oxide ratios in bloom slag from smelting experiments by Peter Crew (XP17, XP23, and XP26)

\begin{tabular}{llllllll}
\hline & $\mathrm{R}^{2}$ for $\mathrm{Al}_{2} \mathrm{O}_{3} / \mathrm{SiO}_{2}$ & $\mathrm{R}^{2}$ for $\mathrm{K}_{2} \mathrm{O} / \mathrm{CaO}$ & $\mathrm{R}^{2}$ for ${\mathrm{MgO} / \mathrm{Al}_{2} \mathrm{O}_{3}}$ & $\mathrm{R}^{2}$ for $\mathrm{Al}_{2} \mathrm{O}_{3} / \mathrm{CaO}$ & $\mathrm{R}^{2}$ for $\mathrm{K}_{2} \mathrm{O} / \mathrm{MgO}$ & $\mathrm{R}^{2}$ for $\mathrm{SiO}_{2} / \mathrm{MgO}^{2}$ & $\mathrm{R}^{2}$ for $\mathrm{Al}_{2} \mathrm{O}_{3} / \mathrm{K}_{2} \mathrm{O}$ \\
\hline $\mathrm{XP17}$ & -1.07 & -2.55 & -1.31 & -0.49 & 0.80 & 0.26 & 0.73 \\
$\mathrm{XP23}$ & -1.18 & -0.97 & -2.22 & -0.06 & -0.48 & 0.22 & 0.33 \\
$\mathrm{XP26}$ & 0.33 & 0.64 & -6.82 & 0.08 & -0.36 & 0.46 & 0.23 \\
\hline
\end{tabular}

Tap slag and furnace slag data was not taken into consideration. Data courtesy Peter Crew.

smelting-derived inclusions (SI10, SI12, SI14, SI15, SI16, SI17, SI19, SI23, SI24 - Observations 1, 3, 5, 6, 7, 8, 9, 13, 14). However, their $R^{2}$ determination coefficients were very far from satisfactory. It was only in two cases (SI17 and SI23 Observations 8 and 13) that the recommended fit was achieved (and only for 4 out of 7 oxide pairs) $-\mathrm{Al}_{2} \mathrm{O}_{3} / \mathrm{SiO}_{2}$, - 5.665; $\mathrm{K} 2 \mathrm{O} / \mathrm{CaO}, 0.938 ; \mathrm{MgO} / \mathrm{Al}_{2} \mathrm{O}_{3},-2.961 ; \mathrm{Al}_{2} \mathrm{O}_{3} / \mathrm{CaO}$, 0.664; $\mathrm{K}_{2} \mathrm{O} / \mathrm{MgO},-6.422 ; \mathrm{SiO}_{2} / \mathrm{MgO}, 0.859 ; \mathrm{Al}_{2} \mathrm{O}_{3} / \mathrm{K}_{2} \mathrm{O}$, 0.809 . The identification approach proposed by Disser et al. (2014) with modifications suggested by Żabiński et al. (2019) produced similar results (Observations 1, 3, 5, 6, 7, 8, 9, 13); however, in this case, it proved impossible to isolate groups which would at least partially pass the $\mathrm{R}^{2}$ verification, as SI17 and SI23 were assigned to different classes.

In this place, it is worth making a short comment on the effectiveness of the $\mathrm{R}^{2}$ verification approach. As stated by Charlton et al. (2012) and demonstrated by many other works, this method is sound and generally performs well. In the case of the aforementioned late medieval or early modern period gun barrel, there was a nearly perfect match between smeltingderived slag inclusions selected with the use of it and those isolated with the PCA-AHC approach. However, as said above, the metal in that artefact in all probability did not undergo many manufacturing stages, as slag inclusions were plenty (several hundreds or more) and in many cases many times larger than those in the discussed couter (Żabiński et al. 2019, 2013-2020, Figs. 7-13, 2023). What is more, even in bloom samples, an ideally linear behaviour of all the NRCs is not always the case. It can be well illustrated by results of examinations of blooms from smelting experiments carried out by Crew (Table 7). These results strongly suggest that the $\mathrm{R}^{2}$-based method of isolation of smelting-derived slag inclusions must be used with care.

Bearing this in mind, it was decided to assume a flexible approach and isolate the possible smelting-derived slag inclusions in two manners. In the "hard selection" only those which were suggested by the PCA-AHC method and additionally passed (albeit partially only) the $\mathrm{R}^{2}$ verification were taken into consideration (SI17 and SI23 - Observations 8 and 13). In the "soft selection", the $\mathrm{R}^{2}$ test was omitted; however, to be on safe side, only those observations which plotted near the origin of the PC biplot were included (SI12, SI17, SI19, SI23, SI24 - Observations 3, 8, 9, 13, 14). Then, an attempt at identifying the smelting process was carried out independently on both groups.
In the next stage, weighted contents* (Eq. 1) and weighted contents** (Eqs. 2 and 3) were calculated. The results can be seen in Tables 8 ("hard selection") and Table 9 ("soft selection").

Results of both calculations are displayed on a graph (Fig. 6). As it can be seen, the "hard selection" approach points out that the metal was obtained in the indirect process. More or less the same is implied by weighted contents** in the "soft selection" method, while weighted contents* may suggest the overlapping zone between both processes.

In view of the fact that the obtained results were not completely conclusive, it was decided to verify them with the logistic regression method. First, subcompositional ratios for relevant NRCs were calculated with the use of Eq. 5, and the results were summed (Table 10). It can be remarked here that it is also possible to apply a modified form of this equation (Eq. 7):

\%oxide $* *=($ sum of $\%$ oxide $*$ in all inclusions $\times 100)$

$$
/(100-\text { sum of } \mathrm{FeO} * \text { in all inclusions })
$$

Eventually, the Logit $(p)$ was calculated in line with Eq. 6 and the $\beta$ parameters as stated in Table 3. The following results were obtained:

"Hard selection": 6.091 (or 6.853 in case the subcompositional ratios are calculated with Eq. 7)

"Soft selection": 5.770 (or 6.956 with Eq. 7)

For the sake of validation of these results, the $p$ value was calculated $\left(p=e^{\operatorname{logit}(p)} /\left(1+\left(e^{\operatorname{logit}(p)}\right) ; e-\right.\right.$ exponential function $)$. What was obtained were:

"Hard selection": 0.998

"Soft selection": 0.997

Then, the $\operatorname{Logit}(p)$ was again calculated; however, this was done with the use of the natural logarithm: Logit $(p)=\ln (p / 1-p)$. The obtained values were 6.091 and 5.770, respectively. As said above, in the case studied by Disser et al. (2014), the $\operatorname{Logit}(p)$ values for the indirect process were between 1.95 and 8.30, while for the direct process, the values were between -18.26 and -2.32 . Therefore, as the obtained results are strongly in the "indirect zone", it seems that there are solid premises to suppose that the couter in question was manufactured from indirect process iron. 


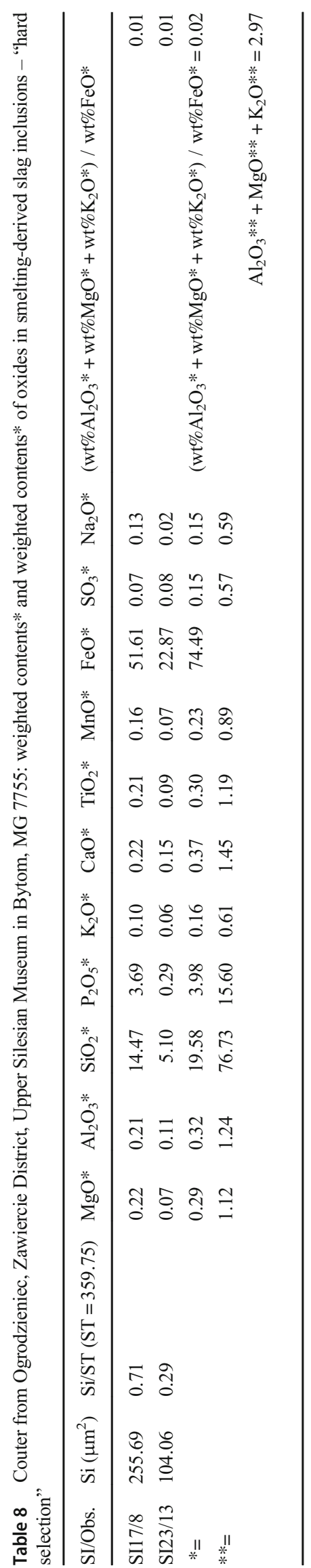

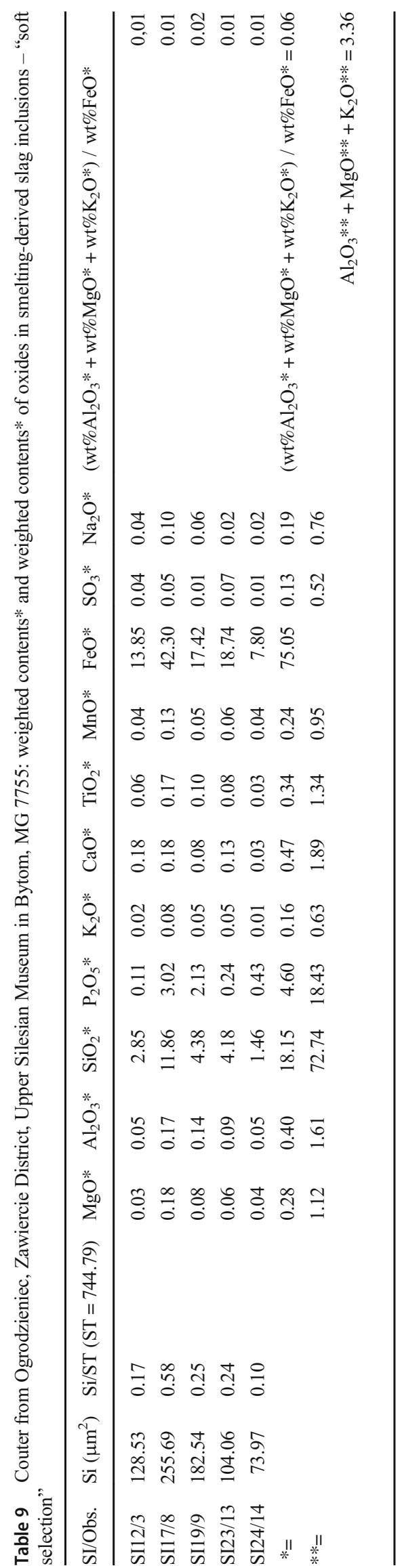



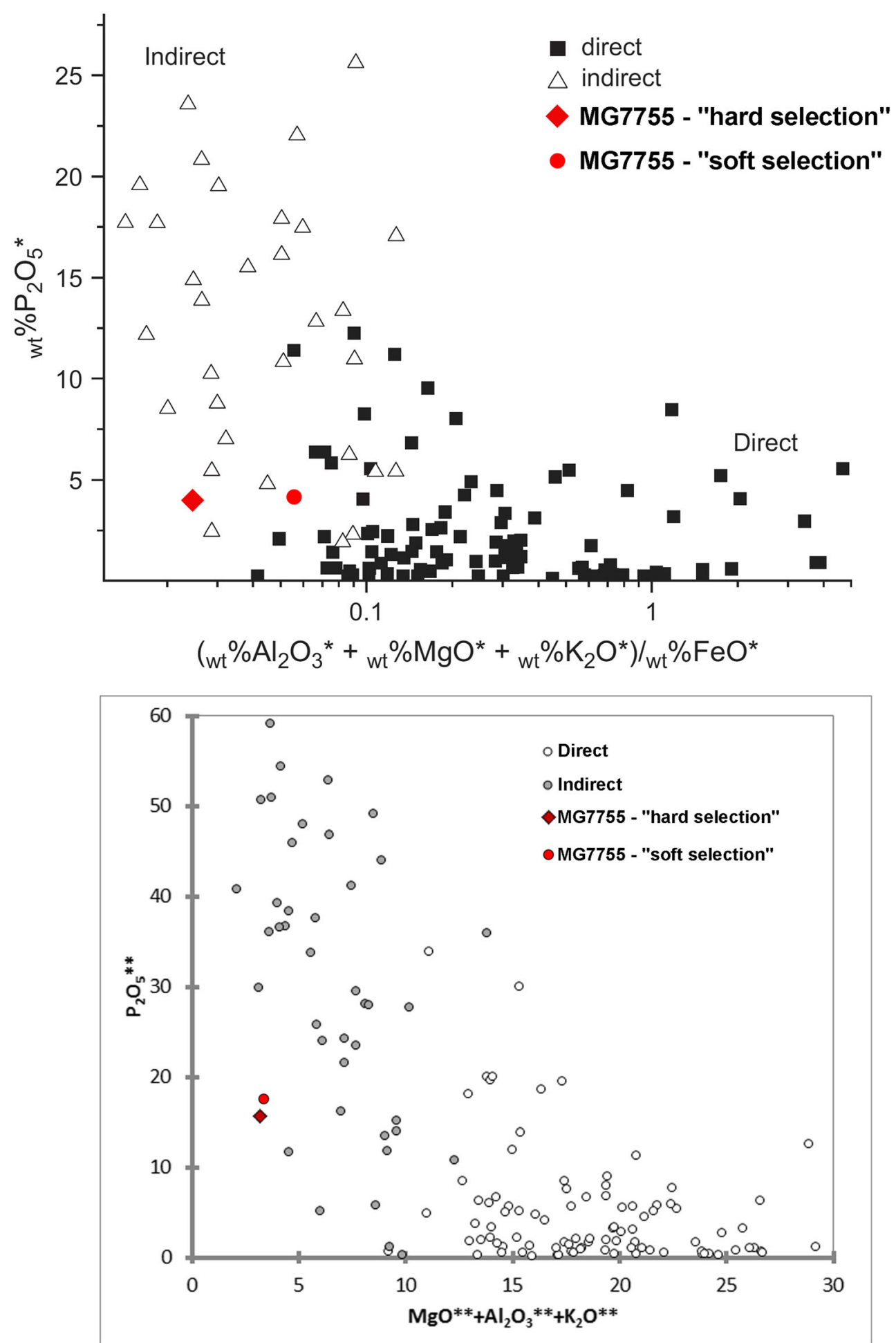

Fig. 6 Couter from Ogrodzieniec, Zawiercie District, Upper Silesian Museum in Bytom, MG 7755: identification of the smelting process "hard selection" (sums of weighted contents* and weighted contents** of selected NRCs in slag inclusions) and "soft selection" (sums of weighted contents* and weighted contents** of selected NRCs in slag inclusions). Background graphs with comparative data - top: after Dillmann and L'Héritier 2007: p. 1819, Fig. 10; bottom: courtesy Dr. Maxime L'Héritier 
Table 10 Couter from Ogrodzieniec, Zawiercie District, Upper Silesian Museum in Bytom, MG 7755: subcompositional ratios of oxides in smelting-derived SIs

\begin{tabular}{|c|c|c|c|c|c|c|c|}
\hline & $\mathrm{MgO}^{* *}$ & $\mathrm{Al}_{2} \mathrm{O}_{3} * *$ & $\mathrm{SiO}_{2} * *$ & $\mathrm{P}_{2} \mathrm{O}_{5} * *$ & $\mathrm{~K}_{2} \mathrm{O} * *$ & $\mathrm{CaO}^{* *}$ & $\mathrm{MnO}^{* *}$ \\
\hline \multicolumn{8}{|c|}{ "Hard selection" } \\
\hline SI total & 0.54 & 0.57 & 36.53 & 8.00 & 0.28 & 0.37 & 0.42 \\
\hline \multicolumn{8}{|c|}{ "Soft selection" } \\
\hline SI total & 0.34 & 0.48 & 22.29 & 5.71 & 0.19 & 0.56 & 0.29 \\
\hline
\end{tabular}

\section{Conclusions and suggestions for further research}

The discussed couter, albeit surviving in a vestigial shape, seems to be of utmost interest. It was made from almost Cfree and high-P iron. This was certainly not proper raw material for high-quality armour, although it must be said that the couter metal was carefully processed. Iron and very lowcarbon steel could be used in less advanced centres and may have been quite common in German or German-influenced armour-making workshops at the turn of the fourteenth and fifteenth century, which is also suggested by the typochronology of the find. On the other hand, metal with a high-P content was rather avoided for the purpose of manufacture of armours, which is why the discussed couter is rather uncommon. In order to see the manufacturing technology of this couter against the background of medieval and early modern ironworking, readers may wish to consult some general works discussing this matter (e.g., Buchwald 2005; id., 2008; Pleiner 2000; id. 2006; Tylecote 1976; Tylecote and Gilmour 1986; Williams 2003; Williams 2012). However, what makes this artefact the most unique is the fact that there are strong grounds to suppose that it was manufactured from refined blast furnace iron and not from bloomery metal. If this is actually the case, it would be a quite early example of the use of such iron in the manufacture of armour, as it has been hitherto believed that refined iron first went into use for this purpose in the early sixteenth century. Furthermore, this would imply that the couter or the metal it was manufactured from was produced beyond the borders of the Kingdom of Poland, as the indirect smelting process first reached this country in the seventeenth century. It must obviously be remembered that armours studied by Williams were not examined with the methods applied in this paper in order to identify the smelting process. Therefore, new research or reexamination of previously analysed examples can possibly reveal new instances of use of refined iron in late medieval armour.

Eventually, it must be also said that the examined couter is an excellent example of difficulties which may be encountered while studying the chemistry of slag inclusions in highly processed ferrous artefacts and while attempting at isolating smelting-derived slag inclusions in order to identify the smelting process.
Acknowledgements The authors are indebted to Dr. Maxime L'Héritier who provided important consultation and supplied comparative data. Thanks must also go to Peter Crew for his kind permission to use his experimental smelting data. Furthermore, Prof. Michael Charlton provided insightful remarks related to isolation of smelting-derived slag inclusions, and Dr. Alan Williams generously shared his knowledge on the metallurgy of plate armour. Dr. Eng Jiři Hošek offered help with regard to the interpretation of microstructures. Eventually, the authors are obliged to Małgorzata Kapczyńska MA, Chief Conservator from the Upper Silesian Museum in Bytom, for her help during the sampling of the artefact. Eventually, thanks must also go to two anonymous reviewers whose comments significantly improved the quality of this paper.

Open Access This article is licensed under a Creative Commons Attribution 4.0 International License, which permits use, sharing, adaptation, distribution and reproduction in any medium or format, as long as you give appropriate credit to the original author(s) and the source, provide a link to the Creative Commons licence, and indicate if changes were made. The images or other third party material in this article are included in the article's Creative Commons licence, unless indicated otherwise in a credit line to the material. If material is not included in the article's Creative Commons licence and your intended use is not permitted by statutory regulation or exceeds the permitted use, you will need to obtain permission directly from the copyright holder. To view a copy of this licence, visit http://creativecommons.org/licenses/by/4.0/.

\section{References}

Archival sources

Dziennik badań w Ogrodzieńcu (1964) Ogrodzieniec-Zamek, pow. Zawiercie, 22 VI - 27 VI 1964 (Journal of excavations in Ogrodzieniec. Ogrodzieniec-Zamek, Zawiercie District, 22-27 June 1964). No. 40. Archive of the Archaeology Department, Upper Silesian Museum in Bytom

Szydłowski J (1964) Sprawozdanie (wstępne) z badań sondażowych na terenie zamku w Ogrodzieńcu, pow. Zawiercie, w dniach 22-30 VI oraz 12-14 X 1964 r. (A preliminary report on test excavations at Ogrodzieniec Castle, Zawiercie District, on 22-30 June and 12-14 October 1964). Dossier 88 Zawiercie Me-P, Folder Ogrodzieniec: Zawiercie. Archive of the Archaeology Department, Upper Silesian Museum in Bytom

Literature

Antoniewicz M (1993) Zamki i ludzie na Wyżynie KrakowskoCzęstochowskiej (Castles and people in the Kraków-Częstochowa Upland). Prace Naukowe Wyższej Szkoły Pedagogicznej w Częstochowie. Zeszyty Historyczne 1: 23-39 
Becker K, Riesch H (2002) Untersuchungen zu Metallurgie und Effizienz merowingerzeitlicher Lamellenpanzer. Archäologisches Korrespondenzblatt 32: 597-606

Blakelock E, Martinón-Torres M, Veldhuijzen HA, Young T (2009) Slag incusions in iron objects and the quest for provenance: an experiment and a case study. J Archaeol Sci 36:1245-1257. https://doi.org/ 10.1016/j.jas.2009.03.032

Buchwald VF (2005) Iron and steel in ancient times. Historisk-filosofiske Skrifter 29. The Royal Danish Academy of Sciences and Letters. Copenhagen

Buchwald VF (2008) Iron, steel and cast iron before Bessemer. Historiskfilosofiske Skrifter 32. The Royal Danish Academy of Sciences and Letters. Copenhagen

Buchwald VF, Wivel H (1998) Slag analysis as a method for the characterization and provenancing of ancient iron objects. Mater Charact 40:73-96. https://doi.org/10.1016/S1044-5803(97)00105-8

Charlton MF, Blakelock E, Martinón-Torres M, Young T (2012) Investigating the production provenance of iron artifacts with multivariate methods. J Archaeol Sci 39:2280-2293. https://doi.org/10. 1016/j.jas.2012.02.037

Charlton MF, Crew P, Rehren T, Shennan SJ (2013) Measuring variation in iron smelting slags: an empirical evaluation of groupidentification procedures. In: Rehren T (ed) Humphris J. The World of Iron, London, pp 421-430

Dillmann P, L'Héritier M (2007) Slag inclusion analyses for studying ferrous alloys employed in French medieval buildings: supply of materials and diffusion of smelting processes. J Archaeol Sci 34: 1810-1823. https://doi.org/10.1016/j.jas.2006.12.022

Disser A, Dillman P, Bourgain C, L'Héritier M, Vega E, Bauvais S, Leroy $M$ (2014) Iron reinforcements in Beauvais and Metz cathedrals: from bloomery or finery? The use of logistic regression for differentiating smelting processes. J Archaeol Sci 42:315-333. https://doi. org/10.1016/j.jas.2013.10.034

Disser A, Dillmann P, Leroy M, L'Héritier M, Bauvais S, Fluzin P (2017) Iron supply for the building of Metz cathedral: new methodological development for provenance studies. Archaeometry 59:493-510. https://doi.org/10.1111/arcm.12265

Dowen, KA (2017) The introduction and development of plate armour in medieval Western Europe, c. 1250-1350. Fasciculi Archaeologiae Historicae 30: 19-28, doi: https://doi.org/10.23858/FAH30.2017. 002

Fulford M, Sim D, Doig A (2004) The production of Roman ferrous armour: a metallographic survey of material from Britain, Denmark and Germany and its implications. J Roman Archaeol 17:197-220

Fulford M, Sim D, Doig A, Painter A (2005) In defence of Rome: a metallographic investigation of Roman ferrous armour from Northern Britain. J Archaeol Sci 32:241-250. https://doi.org/10. 1016/j.jas.2004.09.003

Glinianowicz M (2005) Stan badań nad uzbrojeniem późnośredniowiecznym w Małopolsce (State of research on late medieval weaponry in Lesser Poland). Acta Militaria Mediaevalia 1: $143-164$

Goll M (2014) Iron documents. Interdisciplinary studies on the technology of late medieval European plate armour production between 1350 and $1500 . \mathrm{PhD}$ dissertation, University of Heidelberg, http:// www.ub.uni-heidelberg.de/archiv/17203

Grabarczyk T (1992) Występowanie i zastosowanie zbroi płytowej białej w drugiej połowie XV w. (Occurrence and use of alwite plate armour in the second half of the $15^{\text {th }} \mathrm{c}$.). Acta Universitatis Lodziensis. Folia Historica 50: 77-92

Gruszecki A (1977) Wstępne wyniki badań architektonicznohistorycznych zamku ogrodzienieckiego (Preliminary results of architectural and historical research on Ogrodzieniec Castle). Ochrona Zabytków 30.1-2 (116-117): 44-45
Kajzer L (1976) Uzbrojenie i ubiór rycerski w średniowiecznej Małopolsce w świetle źródeł ikonograficznych (Chivalry's armament and dress in medieval Lesser Poland in the light of iconographic sources). Polska Akademia Nauk, Instytut Historii Kultury Materialnej, Wrocław-Warszawa-Kraków

Klimek L, Strzyż P (2011) Nowe spojrzenie na zbroję ze Spytkowic na marginesie przeprowadzonych analiz metaloznawczych (New look on the armour from Spytkowice as a side note to the metallographic analysis). Acta Miltaria Mediaevalia 7: 215-240

L'Héritier M, Dillman P, Arnaund S, Fluzin P (2013) Iron? Which iron? Methodologies for metallographic and slag inclusion studies applied to ferrous reinforcements from Auxerre cathedral. In: Humphris J. Rehren T, The World of Iron, London, pp 409-420

Lachowska M (2015) Zamek Ogrodzieniec w Podzamczu (Ogrodzieniec Castle in Podzamcze). In: Laska P, Sypczk P (eds) Renovatio et restitutio. Materiały do badań i ochrony założeń rezydencjonalnych i obronnych (Renovatio et restitutio. Materials for research and protection of residential and defensive premises). Instytut Sztuki PAN, Warszawa, pp. 55-66

Maia RR, Dias MS, de Farias Azevedo CR, Landgraf FJG (2015) Archaeometry of ferrous artefacts from Luso-Brazilian archaeological sites near Ipanema River, Brazil, REM. Revista Escola de Minas, Ouro Preto 68.2:187-193, https://doi.org/10.1590/037044672015680151

Mamani-Calcina EA, Landgraf FJG, de Farias Azevedo CR (2017) Investigating the provenance of iron artifacts of the Royal Iron Factory of São João de Ipanema by hierarchical cluster analysis of EDS microanalyses of slag inclusions. Mater Res 20(1):119-129. https://doi.org/10.1590/1980-5373-MR-2016-0444

Marek L (2008) Medieval armour from Szczerba Castle. Acta Militaria Mediaevalia 4: 87-127

Marek L (2014) Castle at war - archaeological records of fighting during the siege of castle Kolno in Silesia. Forschungen zur Archäologie im Land Brandenburg 15: 131-144

Nadolski A (1969) Hełm i fragmenty zbroi z XIV wieku znalezione w Siedlatkowie nad Warta (A helmet and fragments of a fourteenth century armour found in Siedlatków upon Warta). Studia do Dziejów Dawnego Uzbrojenia i Ubioru Wojskowego 4: 5-23

Nadolski A, Wawrzonowska Z (1982) Szczątki zbroi ze Spytkowic (Remains of an armour from Spytkowice). Studia do Dziejów Dawnego Uzbrojenia i Ubioru Wojskowego 8: 21-34

Nowakowski A (1990) Uzbrojenie ochronne (Protective armament). In: Nadolski A (ed) Uzbrojenie w Polsce średniowiecznej 1350-1450 (Arms and armour in medieval Poland 1350-1450). Polska Akademia Nauk, Instytut Historii Kultury Materialnej. Łódź, pp $31-110$

Nowakowski A (1994) Arms and armour in the medieval Teutonic Order's state in Prussia. Studies on the history of ancient and medieval art of warfare 2. Oficyna MS, Łódź

Nowakowski A (2003) Uzbrojenie ochronne (Protective armament). In: Nadolski A (ed) Uzbrojenie w Polsce średniowiecznej 1450-1500 (Arms and armour in medieval Poland 1450-1500). Uniwersytet Mikołaja Kopernika, Toruń, pp 75-108

Nowakowski PA (2006) Arsenały domowe rycerstwa polskiego w średniowieczu (Home armouries of the Polish nobility in the Middle Ages). Wyd. A. Marszałek, Toruń

Oakeshott RE (1999) The archaeology of weapons: arms and armour from prehistory to the Age of Chivalry. Mineola

Oakeshott RE (2000) European weapons and armour. From the Renaissance to the Industrial Revolution, 2nd ed. Boydell, Woodbridge

Piccardo P, Ienco MG, Balasubramanian R, Dillman P (2004) Detecting non-uniform phosphorus distribution in ancient Indian iron by colour metallography. Curr Sci 87(5):650-653

Pleiner R (2000) Iron in archaeology: the European bloomery smelters. Archeologický ústav AV ČR, Praha 
Pleiner R (2006) Iron in archaeology: early European blacksmiths. Archeologický ústav AV ČR, Praha

Szymczak J (2016) Rycerz w hełmie, w zbroi i z tarczą (A knight in a helmet, in an armour and with a shield). DiG, Warszawa

Thiele Á, Hošek J (2015) Estimation of phosphorus content in archaeological iron objects by means of optical metallography and hardness measurements, Acta Polytechnica Hungarica 12.4: 113-126

Tylecote RF (1976) A history of metallurgy. Metals Society, London

Tylecote RF, Gilmour BJJ (1986) The metallography of early ferrous edge tools and edged weapons. British Archaeological Reports. British series 155. Oxford

Vega E, Dillmann P, L'Héritier M, Fluzin P, Crew P, Benoit P (2003) Forging of phosphoric iron. An analytical and experimental approach. In: Archaeometallurgy in Europe: international conference; 24-25-26 September 2003, vol 2. Associazione Italiana di Metallurgia, Milan, pp 337-346

Vella D, Degringy C, Grech M., Williams A (2004) Metallurgy of armour exhibited at the Palace Armoury Valletta, Malta. Proceedings of Metal 2004, 4-8 October 2004. National Museum of Australia, Canberra, pp. 215-233

Wawrzonowska Z (1976) Uzbrojenie i ubiór rycerski Piastów śląskich od XII do XIV wieku (Arms and knightly garments of Silesian Piasts from the $12^{\text {th }}$ to the $14^{\text {th }} \mathrm{c}$.). Acta Archeologica Lodziensia 25. Eódź

Williams AR (2003) The knight and the blast furnace. A history of the metallurgy of armour in the Middle Ages \& the Early Modern Period, Brill, Leiden

Williams AR (2009) The metallurgy of brigandines from Szczerba and Kempten. Acta Militaria Mediaevalia 5:147-160

Williams AR (2011) Further metallographic studies on early armour from Churburg. In: Hošek J, Cleere H, Mihok L (eds) The archaeometallurgy of iron. Recent developments in archaeological and scientific research. Dedicated to Professor Radomir Pleiner. Institute of Archaeology of the ASCR, Praha, pp 163-172

Williams AR (2012) The sword and the crucible. A history of the metallurgy of European swords up to the $16^{\text {th }}$ century. Brill, LeidenBoston

Williams AR, Edge D (2004) Great helms and their development into helmets. Gladius 24:123-134

Williams AR, Edge D (2013) A suit of armour produced by five workshops. Wallace Collection A20. In: Córdoba R (ed) Craft treatises and handbooks. The dissemination of technical knowledge in the Middle Ages. De Diversis Artibus. Collection of Studies from the International Academy of the History of Science, New York-Leiden, pp 197-206

Żabiński G, Biborski M, Biborski M, Stępiński J, Miśta EA (2018) A late medieval or early modern ferrous hackbut barrel from the collection of the castle museum in Malbork, Acta Militaria Mediaevalia 14: $175-212$

Żabiński G, Biborski M, Miśta-Jakubowska EA (2019) A late medieval or early modern light gun barrel from the castle museum in Malbork - typology, technology of manufacture and identification of the smelting process. Archaeol Anthropol Sci 11:2007-2026. https:// doi.org/10.1007/s12520-018-0653-3

Żygulski Z jr (1975) Broń w dawnej Polsce. Na tle uzbrojenia Europy i Bliskiego Wschodu (Arms in Old Poland: against the background of the armament of Europe and the Middle East). Państwowe Wydawnictwo Naukowe, Warszawa

Publisher's note Springer Nature remains neutral with regard to jurisdictional claims in published maps and institutional affiliations. 